\title{
4. BENTONITES AS TRACERS OF EARLIEST CRETACEOUS POST-BREAKUP VOLCANISM OFF NORTHWESTERN AUSTRALIA (LEGS 122 AND 123) ${ }^{1}$
}

\author{
Jürgen Thurow ${ }^{2}$ and Ulrich von $\operatorname{Rad}^{3}$
}

\begin{abstract}
Bentonites (i.e., smectite-dominated, altered volcanic ash layers) were discovered in Berriasian to Valanginian hemipelagic (shelfal) to eupelagic (deep-sea) sediments of the Wombat Plateau (Site 761), Argo Abyssal Plain (Sites 261, 765), southern Exmouth Plateau (Site 763), and Gascoyne Abyssal Plain (Site 766).

A volcaniclastic origin with trachyandesitic to rhyolitic ash as parent material is proved by the abundance of well-ordered montmorillonite, fresh to altered silicic glass shards, volcanogenic minerals (euhedral sanidine, apatite, slender zircon), and rock fragments, and by a vitroclastic ultra-fabric (smectitized glass shards).

For the Argo Abyssal Plain, we can distinguish four types of bentonitic claystones of characteristic waxy appearance: (1) pure smectite bentonites, white to light gray, sharp basal contacts, and a homogeneous cryptocrystalline smectite matrix, (2) thin, greenish-gray bentonitic claystones having sharp upper and lower contacts, (3) gray-green bentonitic claystones mottled with background sedimentation and a distinct amount of terrigenous and pelagic detrital material, and (4) brick-red smectitic claystones having diffuse sedimentary contacts and a doubtful volcanic origin. For the other drill sites, we can distinguish between (1) pure bentonitic claystones similar in appearance and chemical composition to Type 1 of the Argo Abyssal Plain (except for gradual basal contacts) and (2) impure bentonitic claystones containing textures of volcanogenic smectite and pyroclastic grains with terrigenous and pelagic components resulting from resedimentation or bioturbation.

The ash layers were progressively altered (smectitized) during diagenesis. Silicic glass was first hydrated, then slightly altered (etched with incipient smectite authigenesis), then moderately smectitized (with shard shape still intact), and finally, completely homogenized to a pure smectite matrix without obvious relict structures.

Volcanic activity was associated with continental breakup and rapid subsidence during the "juvenile ocean phase." Potential source areas for a Neocomian post-breakup volcanism include Wombat Plateau, Joey and Roo rises, Scott Plateau, and Wallaby Plateau/Cape Range Fracture Zone. Westward-directed trade winds transported silicic ash from these volcanic source areas to the Exmouth Plateau and, via turbidity currents, into the adjacent abyssal plains. The Wombat and Argo abyssal plain bentonites are interpreted, at least in parts, as proximal or distal ash turbidites, respectively.
\end{abstract}

\section{INTRODUCTION}

One of the most exciting, but poorly understood, themes of passive margin evolution is the study of tectonic, volcanic, and sedimentary environments following continental breakup at the margin and the formation of a "juvenile ocean" in the adjacent rapidly subsiding and growing young ocean basins (von Rad and Exon, 1983). During ODP Legs $122 / 123$, scientists recovered a terrigenous to hemipelagic "juvenile ocean" sequence of early Neocomian age at Site 761 on the Wombat Plateau and at Site 766 at the edge of the Gascoyne Abyssal Plain (Figs. 1A, 1B, and 2), sections that contained a number of bentonite layers in addition to other conspicuous lithofacies, such as belemnite-rich sands, volcaniclastic sands, and calcisphere nannofossil chalks (Shipboard Scientific Party, 1990a, 1990b). Similar, co-eval bentonitic clays in the adjacent Argo Abyssal Plain Site 765 are intercalated in a sequence, dominated by pelagic claystone with radiolarites and carbonate turbidites (Shipboard Scientific Party, 1990b).

The bentonite layers in these (and a few other) drill holes are the first discoveries of an important early Neocomian phase of "post-break-up volcanism" (von Rad and Thurow, 1992). While an extensive literature exists about volcanogenic sedimentation in back-arc basins (Carey and Sigurdson, 1984; von Rad and Mühe,

\footnotetext{
${ }^{1}$ Gradstein, F. M., Ludden, J. N., et al., 1992. Proc. ODP, Sci. Results, 123: College Station, TX (Ocean Drilling Program).

${ }^{2}$ Geology Department, Tübingen University, F.R.G. Present address: Geologisches Institut, Ruhr-Universität Bochum, D-4630 Bochum, F.R.G.

3 BGR, Hannover, F.R.G.
}

1990), the phenomenon of volcaniclastic deposition at divergent plate boundaries (passive margins) just after continental breakup has received little attention.

This is the second study in a series of publications related to the volcanic evolution of the northern margin of Gondwana. We principally discuss the Early Cretaceous bentonites found in the Argo Abyssal Plain (Site 765; with a brief comparison with occurrences in other sites in the vicinity). An earlier study (von Rad and Thurow, 1992) describes the bentonite found in Leg 122 sites (Figs. 1A and 1B) in detail, although in the more general parts of the two studies, some overlapping does occur.

The objectives of this study are (1) to describe the composition of bentonite layers, using optical, mineralogical, scanning electron microscopical, geochemical (XRF), and clay-mineralogical (XRD) methods; (2) to discuss the occurrence of Leg 122/123 bentonites in the framework of the plate-tectonic and paleogeographical settings, and (3) to draw preliminary conclusions as to the type and significance of early Neocomian post-breakup volcanism off northwestern Australia (source areas, mode of deposition, redeposition, and alteration of the ash layers).

Here, we use the term "bentonite" loosely, as suggested by Grim and Güven (1978), Fisher and Schmincke (1984), and Schmincke (1989): bentonites are smectite-dominated clays that originated as volcanic ash layers, mostly of rhyolitic to dacitic composition, and that have been more or less completely altered ("argillized") in situ into smectite in a subaqueous environment; submarine bentonites are distinct layers, generally characterized by small thickness, wide lateral extent, vitroclastic texture, and the presence of euhedral (high-temperature) minerals (e.g., sanidine, biotite, zircon, apatite; cf. Zimmerle, 1989). 

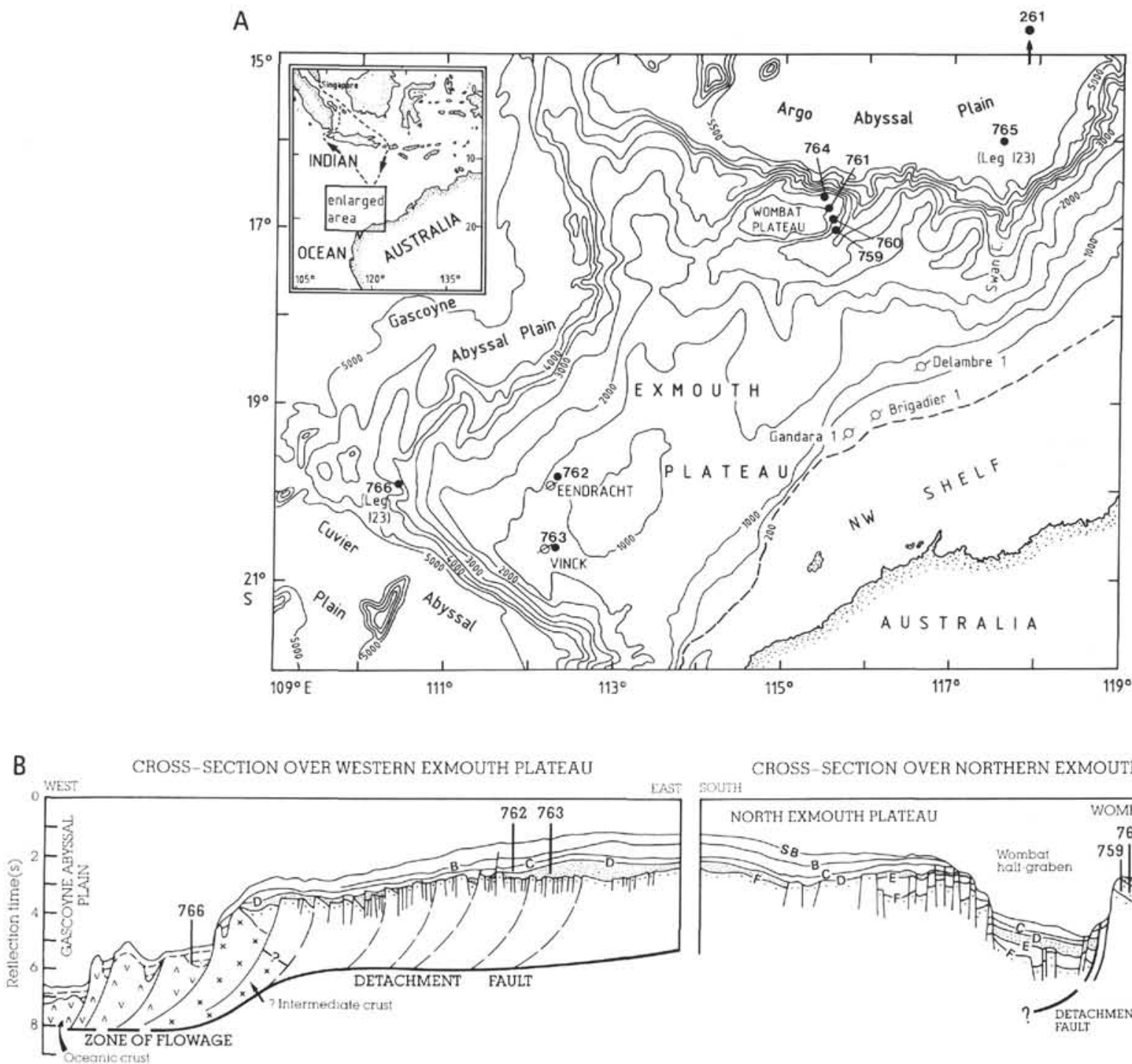

CROSS-SECTION OVER NORTHERN EXMOUTH PLATEAU
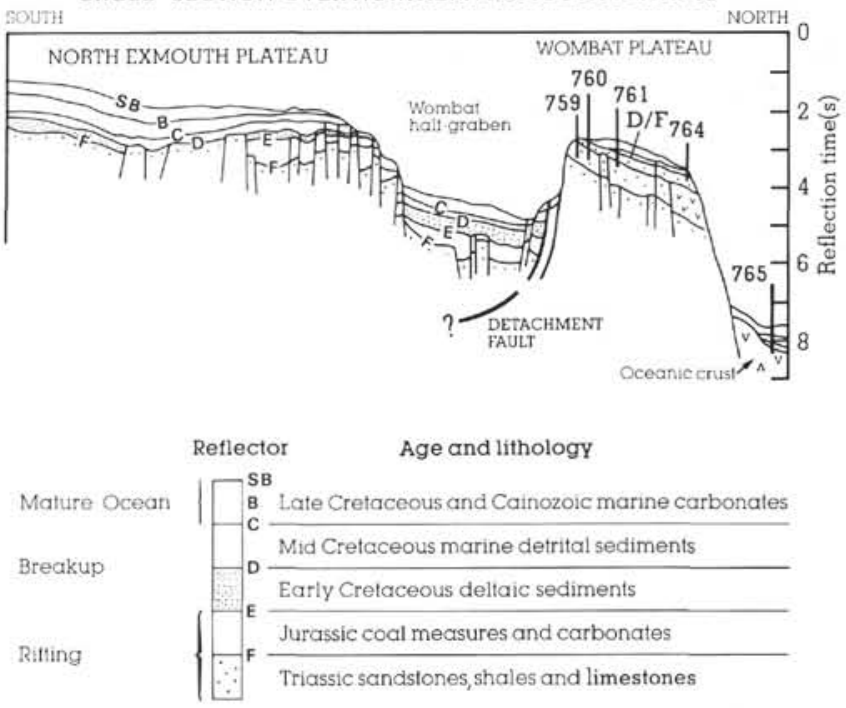

Figure 1. A. Location of Legs 122/123 sites (black dots) on Exmouth Plateau and vicinity. The ocean/continent boundary coincides roughly with the steep escarpment between Exmouth Plateau (continental crust) and the surrounding deep-ocean basins (Argo, Gascoyne, and Cuvier abyssal plains). Bathymetry in meters (Exon, unpubl. data). B. Schematic east-west and north-south sections across Exmouth Plateau and adjacent abyssal plains with approximate location of ODP sites. C. DSDP sites in the vicinity of Legs 122/123. 


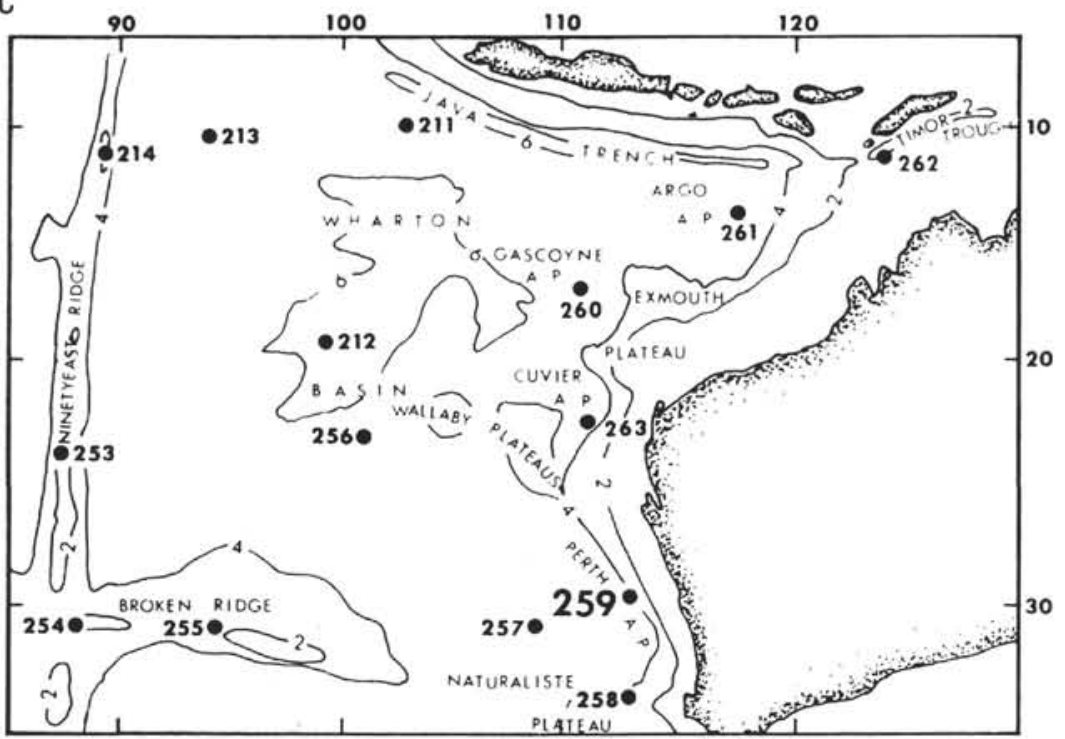

Figure 1 (continued).

The Leg 122/123 "bentonites" can be subdivided into (1) "pure smectite bentonites" containing less than a few percent pelagic and nonvolcanic terrigenous components and (2) "impure bentonites" that comprise a wide range of mixtures of volcanogenic smectite and pyroclastic grains with nonvolcanic (terrigenous and pelagic) components.

\section{METHODS}

Samples were prepared for optical (thin sections, ultra-thin sections), electron microscopy (scanning electron [SEM], EDAX, backscattering), mineralogical (X-ray diffraction [XRD] of clay minerals and coarse fraction), and chemical (XRF) investigations. A summary is presented in Table 1. Either bulk samples or separate mineral fractions $>38 / 32,>20,>2,<2$, and $<<2 \mu$ m were used. The preparation procedure followed the shipboard method (Shipboard Scientific Party, 1990b).

We investigated about 80 bentonite samples by integrated optical mineralogical methods, XRD analysis, X-ray fluorescence (XRF) geochemistry, and SEM (Tables 2 and 3). Optical mineralogy was performed using smear slides of bulk material and highly polished, $10-\mu \mathrm{m}$-thick thin sections. Most bentonite samples were processed with $\mathrm{H}_{2} \mathrm{O}_{2}$ and ultrasonic vibration, sieved ( 20 and $63 \mu \mathrm{m}$ ); in part, the $<2-\mu \mathrm{m}$ fraction was separated by the Atterberg method or centrifuging. The $>20-\mu \mathrm{m}$ (or $>63$ ) fraction was investigated under the microscope as coarse fraction mounts.

The coarse fraction ( $>20 \mu \mathrm{m}$ for Leg 123 sites and $>32 \mu \mathrm{m}$ for Leg 122 sites) was prepared using several washing, sieving, and centrifuging steps to obtain the different mineral fractions (Fig. 3 ). The coarse fraction was used to determine type and amount of heavy minerals and the degree of detrital contamination (either primary or from underlying/overlaying horizons as a result of molding or poor sampling). Heavy minerals were separated with a heavy liquid (bromoform, polywolframate) and studied by optical and SEM techniques.

XRD was performed on a large number of samples from the $<2 \mu \mathrm{m}$ fractions (at Tübingen and on board the ship) and $<2$ or $<32 \mu \mathrm{m}$ fractions, at BGR and Tübingen. Instrument conditions were as follows: (1) $\mathrm{Cu} \mathrm{K} \alpha, \mathrm{X}$-radiation with Ni filter; $40 \mathrm{kV}$, $35 \mathrm{~mA}$; goniometer scan from $2^{\circ}$ to $70^{\circ}$.

Our semiquantitative XRD results are shown in Table 1 and Figure 4. XRD analyses give only qualitative estimates of mineral composition. Therefore, the results were plotted using the relative peak intensity of each mineral. The peak area of the smectite-001 peak was divided by three.

Three selected samples were analyzed by R. Petschik (AWI, Bremerhaven) to detect the type of smectite that formed the bentonites.

XRF geochemical analyses of 12 major and 24 trace elements were obtained from 30 selected samples (XRF laboratory of the BGR; see Table 2).

SEM analyses of selected bulk samples and some coarse fractions or hand-picked minerals were performed by both authors, mainly at the Tübingen Institute, partly also at BGR. These analyses provided important insights into the ultra-fabric; the detrital, volcanogenic, and authigenic minerals; and the fossils of the investigated bentonites. The application of energy- dispersive $\mathrm{X}$-ray fluorescence (EDX) also allowed us to identify the chemistry and mineralogy of any unknown components (Plates 2 through 4).

\section{GEOLOGICAL AND STRATIGRAPHIC SETTING OF LEG 122/123 BENTONITES}

Bentonitic clays were found in Berriasian-Valanginian sections of ODP Sites 761, 763, 765, and 766, and DSDP Site 261 (Figs. 1A, 1B). We briefly describe the geological and structural setting of these drill sites (von Rad and Thurow, 1992; Haq, von Rad, O'Connell, et al., 1990; Ludden, Gradstein, et al., 1990).

\section{Site 765 in the Argo Abyssal Plain}

Site 765 is located on the Argo Abyssal Plain (AAP), northwest of Australia in the Indian Ocean (Figs. 1A, 1B). This ancient ocean floor is being subducted beneath the Banda Sunda Arc along the Timor Trough to the north (Barber, 1988). To the south lies the Northwest Shelf of Australia. Site 765 was drilled to study the sedimentation history and crustal geochemistry of what was thought to be one of the oldest sections of present-day seafloor (Veevers, Heirtzler, et al., 1974; Heirtzler et al., 1978; Fullerton et al., 1989). Upper Jurassic (Oxfordian; M26) oceanic crust was expected, but no Jurassic sediments were found. It appears that volcanic basement at this site is Berriasian (on the basis of the late Berriasian or early Valanginian age of the oldest dated sediments and extrapolation of sedimentation rate curves (Shipboard Scientific Party, 1990b; Ludden, Gradstein, et al., 1990). A Cretaceous age for oceanic basement at Site 765 necessitates revision of most 


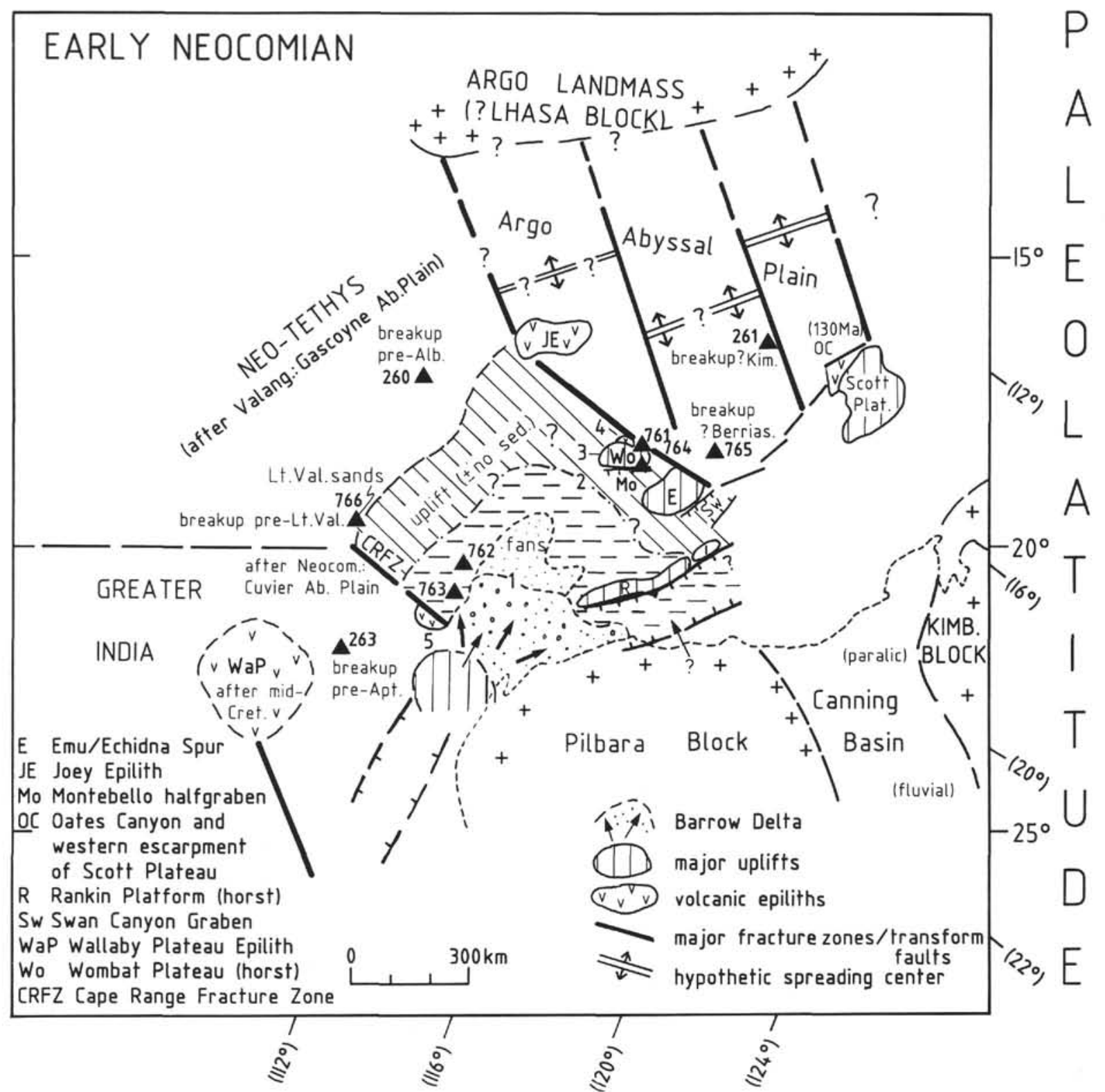

Figure 2. Paleogeographic map of the northwestern Australian margin and vicinity during early Neocomian (Berriasian to Valanginian) time, after the opening of Argo Abyssal Plain and before the separation of greater India and Australia. Sketch map was modified after Barber (1982), von Rad and Exon (1983), Kopsen and McGann (1985), Bradshaw et al. (1988), Boote and Kirk (1989), and Gradstein et al. (1989). 1 = maximum outer shelf break (outer limit of "Barrow Delta"), 2 = outer limit of Berriasian-Valanginian clastic supply (prodelta, etc., onlap edge), 3 = transgressive lower Neocomian sand and calcisphere chalk/bentonite series on Wombat Plateau, $4=$ Rhaeto-Liassic older volcanics (northern Wombat escarpment), $5=$ mid-Berriasian volcanic intrusion. Paleolatitude after Ogg in Gradstein et al. (1989). Present-day latitude and longitude in brackets.

recent published reconstructions of late Mesozoic tectonic history of the northwestern Australian margin and adjacent parts of the Indian Ocean (e.g., Powell, 1976; Cook et al., 1978; Heirtzler et al., 1978; Veevers and Cotterill, 1979; von Rad and Exon, 1983; Veevers, 1988), which are based on a report of possible Late Jurassic sediment overlying basement at DSDP Site 261, also in the AAP (Veevers, Heirtzler, et al., 1974). Jurassic break-up along the northeastern rim of Gondwanaland quickly led to an abyssal oceanic graben north of the Exmouth and Wombat plateaus in the present-day AAP. From Earliest Cretaceous time onward, less than $1000 \mathrm{~m}$ of clayey sediments accumulated in this abyssal environment. Using the Berriasian age (142 Ma) for basement and the present water depth of $5728 \mathrm{~m}$ at Site 765 , one can calculate a backtrack curve. Site 765 apparently began near $2600 \mathrm{~m}$ during Berriasian time. About $935 \mathrm{~m}$ of sediment, ranging in age from Earliest Cretaceous to Holocene, was cored at Site 765. The lower part of the sediment column (Berriasian or Valanginian) consists of silty claystone with abundant calcareous shell fragments. Calcareous silty claystones may represent distal fan or delta deposits in a rift basin partially isolated from Tethys. Nannofossil-bearing claystones might be background hemipelagic deposits, as might the noncalcareous basal claystone just above the sediment/basement contact. Noncalcareous claystones, silty claystones, and clayey siltstones become abundant in lower Valanginian to upper 
Table 1. Sample data, color, age, lithology, sedimentary structure, optical mineralogy, XRD and SEM analyses of selected investigated bentonitic claystones from Leg 123 .

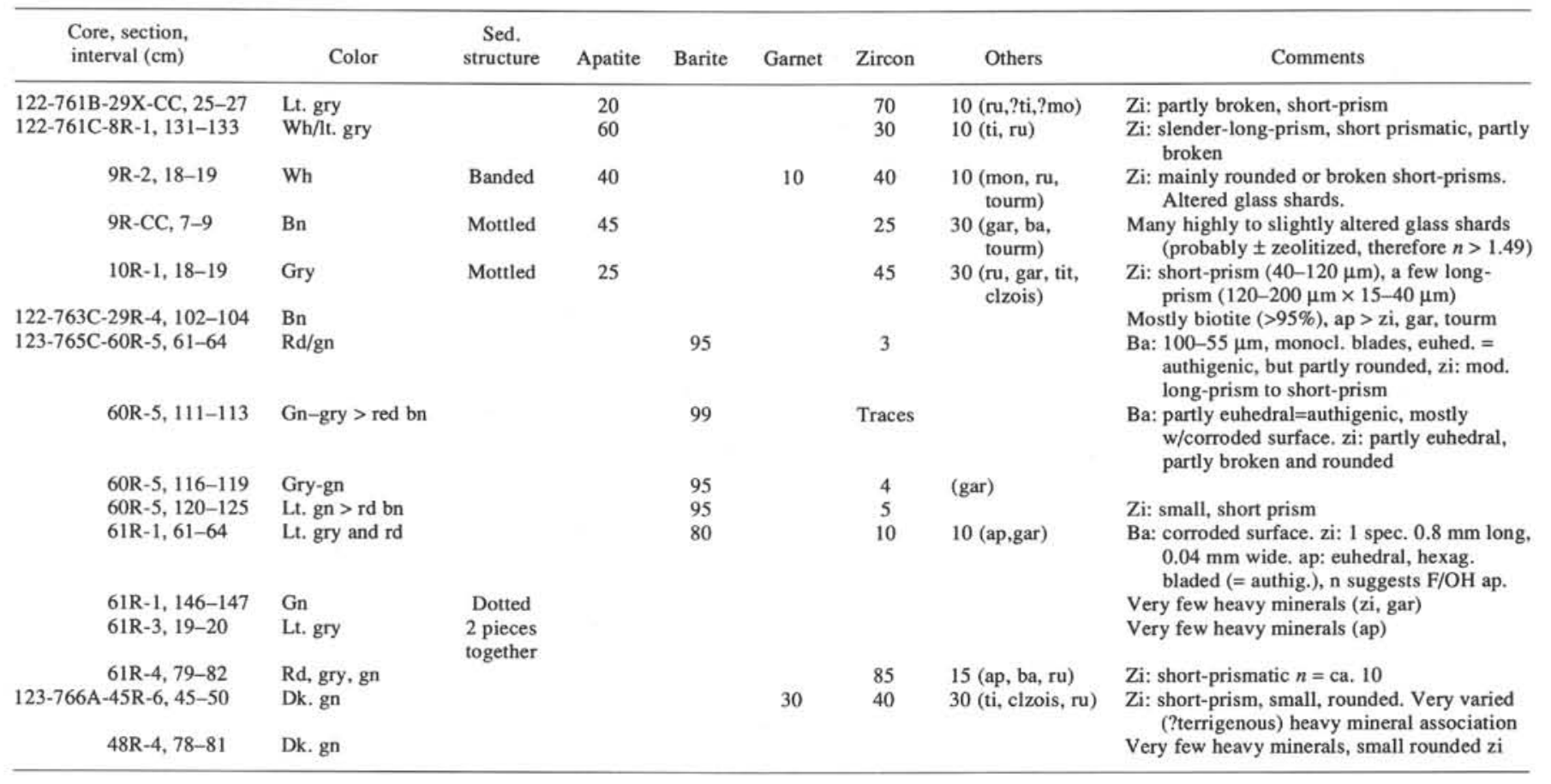

Note: For comparison with Leg 122, see von Rad and Thurow (1992). Definitions: Lithology = host bn claystone, Bi, Bp, chalk. Sedimentary texture = banded, homogeneous, heterogeneous mottled. Contacts $=$ basal sharp. Abundance (XRD): 5 abundant $(>50 \%), 4=$ common $(25 \%-40 \%), 3=$ present $(10 \%-25 \%), 2=$ few $(2 \%-16 \%), 1$ rare (traces, $<2 \%$ ). Minerals: $\mathrm{ca}=$ calcite, do $=$ dolomite, $\mathrm{q}=$ quartz, $\mathrm{fs}=$ feldspar, $\mathrm{m}$-il $=$ muscovite $-\mathrm{illite}$, bi biotite, $\mathrm{gc}=\mathrm{glauconite}, \mathrm{cli}=\mathrm{clinoptilolite,} \mathrm{zeo}=\mathrm{zeolite}, \mathrm{py}=$ pyrite, $\mathrm{am}=\mathrm{X}$-ray amorphous component, $\mathrm{ap}=$ apatite, $\mathrm{ba}=$ barite $, \mathrm{zi}=\mathrm{zircon}, \mathrm{HM}=$ heavy minerals, $\mathrm{sm}=\mathrm{smectite}, \mathrm{x}=\mathrm{crystal}, \mathrm{xx}=\mathrm{crystals}$. Color: wh $=$ white, $\mathrm{pk}=$ pink, $r d=$ red, $b$-rd $=$ brick-red, yel $=$ yellow, gry $=$ gray, $g n=$ green, $b n=$ brown, $\mathrm{lt} .=$ light $, d k,=$ dark., $v,=$ very .

General abbreviations: $\mathrm{Bp}=$ bentonite pure $=100 \%$ smectite, $\mathrm{Bi}=$ bentonite impure $=$ dominant smectite + hemipelagic material $($ mixed volcanic, terrestrial, authigenic, and pelagic material).

0

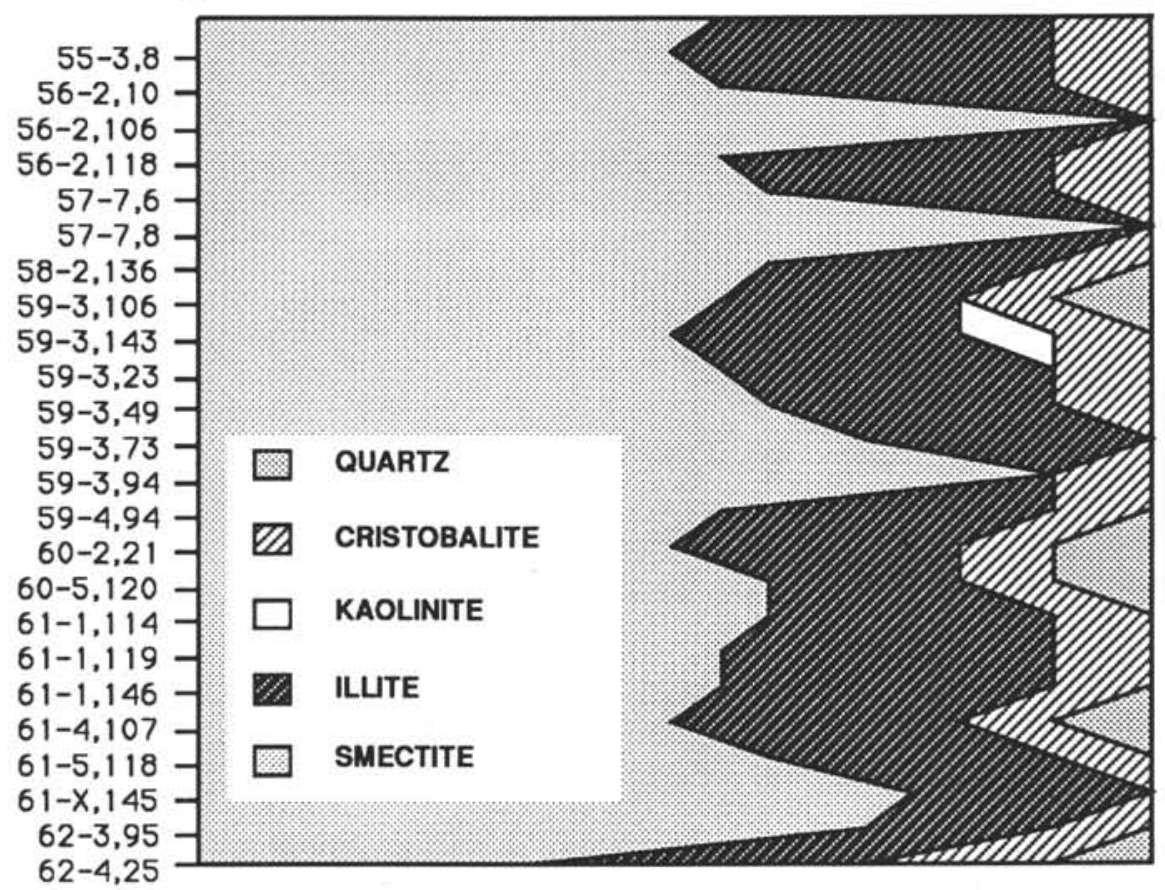

Figure 3. Mineralogy $(<2 \mu \mathrm{m})$ of basal sediments in Hole $765 \mathrm{C}$. Proportions are calculated using peak height and peak intensities. Kaolinite can be interpreted as terrigenous influx. 
Table 2. Color and chemical composition (major and minor elements, XRF analysis).

\begin{tabular}{|c|c|c|c|c|c|c|c|c|c|c|c|c|c|}
\hline $\begin{array}{l}\text { Core, section, } \\
\text { interval }(\mathrm{cm})\end{array}$ & $\begin{array}{l}\text { Lab } \\
\text { no. }\end{array}$ & Color & $\begin{array}{l}\text { Size } \\
(\mu \mathrm{m})\end{array}$ & Purity & $\begin{array}{c}\mathrm{SiO}_{2} \\
(\%)\end{array}$ & $\begin{array}{l}\mathrm{TiO}_{2} \\
(\%)\end{array}$ & $\begin{array}{c}\mathrm{Al}_{2} \mathrm{O}_{3} \\
(\%)\end{array}$ & $\begin{array}{c}\mathrm{Fe}_{2} \mathrm{O}_{3} \\
(\%)\end{array}$ & $\begin{array}{c}\mathrm{MnO} \\
(\%)\end{array}$ & $\begin{array}{r}\mathrm{MgO} \\
(\%)\end{array}$ & $\begin{array}{r}\mathrm{CaO} \\
(\%)\end{array}$ & $\begin{array}{c}\mathrm{Na}_{2} \mathrm{O} \\
(\%)\end{array}$ & $\begin{array}{l}\mathrm{K}_{2} \mathrm{O} \\
(\%)\end{array}$ \\
\hline $122-761$ B-29X-CC, $25-27$ & 87130 & Lt.gry & $<20$ & Bi (B5) & 67.04 & 0.19 & 19.11 & 2.60 & 0.01 & 7.14 & 0.73 & 2.04 & 0.88 \\
\hline $122-761 C-7 R-1,63-65$ & 87121 & $\mathrm{Gn} / \mathrm{pk}$ & $<32$ & $\mathrm{Bi}(\mathrm{B} 6)$ & 60.03 & 0.50 & 16.33 & 6.33 & 0.01 & 6.99 & 1.36 & 3.04 & 0.97 \\
\hline $8 R-1,131-133$ & 87123 & Wh/lt.gry & $<32$ & Bp (B5) & 68.66 & 0.19 & 19.73 & 2.64 & 0.01 & 6.95 & 0.63 & 0.39 & 0.54 \\
\hline $8 R-2,21-23$ & 87124 & Lt. gry & $2-32$ & $\mathrm{Bi}$ (B4) & 66.18 & 0.26 & 18.49 & 2.74 & 0.01 & 6.41 & 3.19 & 1.34 & 1.01 \\
\hline $9 \mathrm{R}-2,18-19$ & 87125 & Wh & $<32$ & Bp (B3) & 68.78 & 0.31 & 18.80 & 3.40 & 0.01 & 6.57 & 0.71 & 0.42 & 0.65 \\
\hline 9R-CC, 7-9 & 87126 & Brn & $<32$ & $\mathrm{Bi}(\mathrm{B} 2)$ & 62.85 & 2.08 & 14.58 & 11.29 & 0.34 & 4.47 & 1.18 & 0.27 & 2.49 \\
\hline $10 \mathrm{R}-1,18-19$ & 87127 & Gry & $<32$ & $\mathrm{Bi}(\mathrm{B} 1)$ & 67.81 & 0.35 & 17.99 & 4.03 & 0.35 & 6.09 & 1.88 & 0.29 & 0.78 \\
\hline $10 \mathrm{R}-1,35-37$ & 87128 & $\mathrm{Pk}$ & $<2$ & Bp (B1) & 68.06 & 0.31 & 18.69 & 3.77 & 0.02 & 6.74 & 0.30 & 1.12 & 0.61 \\
\hline 123-765C-58R-5, 99-101 & 88893 & Lt. gn>rd & & & 75.77 & 0.82 & 10.33 & 5.25 & 0.09 & 2.58 & 0.80 & 1.79 & 1.61 \\
\hline $59 \mathrm{R}-3,94-96$ & 88894 & Lt. gy>lt. gn & & & 63.84 & 1.42 & 20.42 & 2.19 & 0.10 & 3.43 & 1.52 & 2.25 & 2.63 \\
\hline $60 \mathrm{R}-1,84-86$ & 88227 & & & & 69.88 & 0.70 & 14.07 & 5.57 & 0.26 & 2.99 & 1.14 & 1.22 & 3.04 \\
\hline $60 \mathrm{R}-1,112-115$ & 87133 & Brn-rd & bulk & & 71.52 & 0.54 & 11.66 & 8.00 & 0.16 & 2.29 & 1.15 & 1.28 & 2.64 \\
\hline $60 \mathrm{R}-1,120-123$ & 87134 & & bulk & & 71.94 & 0.60 & 12.25 & 5.85 & 0.20 & 2.44 & 1.60 & 1.24 & 2.72 \\
\hline $60 \mathrm{R}-3,16-20$ & 88895 & Gn-gy>red bn & & & 68.13 & 1.06 & 14.88 & 5.64 & 0.08 & 3.16 & 0.99 & 1.98 & 3.04 \\
\hline $60 \mathrm{R}-3,61-64$ & 88896 & Lt. gn>rd bn & & & 64.50 & 0.56 & 20.45 & 2.14 & 0.14 & 5.33 & 1.70 & 3.13 & 0.70 \\
\hline $60 \mathrm{R}-4,32-36$ & 87135 & Gn (rd) & bulk & & 70.19 & 0.65 & 13.26 & 6.46 & 0.10 & 2.72 & 1.03 & 1.92 & 2.85 \\
\hline $60 \mathrm{R}-5,61-64$ & 87136 & $\mathrm{Rd} / \mathrm{gn}$ & $<20$ & & 67.41 & 0.63 & 19.82 & 2.55 & 0.11 & 4.70 & 1.37 & 1.68 & 1.01 \\
\hline $60 \mathrm{R}-5,116-119$ & 87137 & Gry-gn & $<2$ & & 68.08 & 0.29 & 20.10 & 3.37 & 0.05 & 5.53 & 0.95 & 0.51 & 0.70 \\
\hline $60 \mathrm{R}-5,116-119$ & 88897 & Only lt. gn & & & 66.12 & 0.24 & 19.94 & 1.90 & 0.08 & 6.04 & 1.46 & 2.66 & 0.71 \\
\hline $60 \mathrm{R}-5,120-123$ & 87138 & & $<20$ & & 67.22 & 0.20 & 21.20 & 0.83 & 0.09 & 5.86 & 1.46 & 2.44 & 0.36 \\
\hline $61 \mathrm{R}-1,33-36$ & 87141 & B-rd & & & 66.49 & 0.87 & 14.43 & 8.50 & 0.38 & 2.67 & 0.82 & 1.56 & 3.42 \\
\hline $61 \mathrm{R}-1,50-52$ & 88898 & Red bn > lt. gn & & & 63.74 & 0.76 & 16.84 & 7.54 & 0.09 & 4.60 & 1.34 & 2.13 & 2.05 \\
\hline $61 \mathrm{R}-1,61-64$ & 87139 & & & & 65.61 & 0.41 & 18.68 & 3.92 & 0.05 & 5.99 & 1.35 & 2.92 & 0.63 \\
\hline $61 \mathrm{R}-1,61-64$ & 87140 & Lt. gry and rd & $<2$ & & 67.86 & 0.41 & 19.43 & 3.96 & 0.05 & 6.31 & 0.97 & 0.41 & 0.30 \\
\hline $61 \mathrm{R}-2,52-56$ & 88899 & Only red bn & & & 64.08 & 1.29 & 14.07 & 10.41 & 0.27 & 2.43 & 1.14 & 1.32 & 4.27 \\
\hline $61 \mathrm{R}-4,71-74$ & 88228 & & & & 60.66 & 1.03 & 14.89 & 7.62 & 1.38 & 4.05 & 5.60 & 1.25 & 1.25 \\
\hline $61 \mathrm{R}-4,79-82$ & 87143 & Rd & & & 62.38 & 0.91 & 15.99 & 7.79 & 0.15 & 4.48 & 3.40 & 2.42 & 1.89 \\
\hline $61 \mathrm{R}-4,79-82$ & 87144 & Gry & & & 64.81 & 0.98 & 17.19 & 4.54 & 0.17 & 5.00 & 2.81 & 2.06 & 1.83 \\
\hline $6 \mathrm{IR}-4,79-82$ & 87148 & $\mathrm{Gn}$ & $<20$ & & 65.80 & 1.01 & 17.95 & 4.39 & 0.15 & 5.11 & 2.13 & 1.04 & 1.84 \\
\hline $61 \mathrm{R}-4,79-82$ & 87149 & $\mathrm{Rd}$ & $<20$ & & 63.60 & 0.98 & 16.46 & 8.10 & 0.13 & 4.59 & 2.25 & 1.37 & 2.01 \\
\hline $123-766 \mathrm{~A}-48 \mathrm{R}-2,142-147$ & 87145 & Dk. gry & $<2$ & $\mathrm{Bi}$ & 64.55 & 0.24 & 19.26 & 8.81 & 0.01 & 4.31 & 1.27 & 0.86 & 0.29 \\
\hline $48 \mathrm{R}-2,142-147$ & 87146 & & bulk & $\mathrm{Bi}$ & 63.16 & 0.23 & 18.73 & 8.77 & 0.01 & 4.34 & 1.18 & 2.59 & 0.49 \\
\hline $48 \mathrm{R}-4,78-81$ & 87147 & Dk. gn & bulk & $\mathrm{Bi}$ & 62.03 & 0.72 & 17.80 & 8.88 & 0.01 & 3.74 & 1.97 & 2.34 & 1.63 \\
\hline
\end{tabular}

Leg 122 samples: pure bentonites (Bp) and impure bentonites (Bi). All major elements calculated for LOI-free, assuming that most of LOI corresponds to smectite-bound $\mathrm{H}_{2} \mathrm{O}(11 \%-19 \%)$. Samples were not desalinated ( $\mathrm{Na}_{2} \mathrm{O}$ values may be too high-an assumption not confirmed by $\mathrm{SEM}$ investigations). For abbreviations see Table 1.

Berriasian sediments, but are less frequent in lowermost Hauterivian to upper Valanginian, and predominate in upper-to-middle early Aptian to Barremian sediments. These lithologies may be "background" hemipelagic deposits that accumulated beneath the calcite compensation depth (CCD). However, the isolated occurrences of parallel and possible convolute laminae in these lithologies suggest that they may represent, at least in part, siliciclastic mass flow deposits, for example, fine-grained distal turbidites. Greenish-gray to gray claystones provisionally interpreted as bentonites occur in the lowermost part of the section. They appear waxy and have a soapy texture. The recognition of degraded glass shards and feldspar crystals (in smear slides and thin sections) and of montmorillonitic (smectitic) clays (in XRD analyses) supports their interpretation as altered volcanic ashes.

Basal turbidites may have been derived from the south. A possible source for the calcareous sediments is the Wombat Plateau. Site 761 on the central Wombat Plateau contains $20 \mathrm{~m}$ of Neocomian chalk. This chalk contains calcisphere and nannofossil assemblages similar to those found at the base of Site 761 and is thought to have been deposited at upper bathyal depths (Leg 122 Shipboard Scientific Party, unpubl. data, 1989).

Distinct radiolarite intervals occur between Cores 123-765C$51 \mathrm{R}$ and $-59 \mathrm{R}$. Sand- to silt-size radiolarians form thin distinct radiolarite intervals that exhibit sedimentary features, such as parallel and/or wavy laminae that are graded, normal, and (locally) reversed. Boundaries are commonly sharp and locally diffuse to gradational at the top. These characteristics clearly indicate redeposition and concentration of radiolarians by hydrodynamic processes; e.g., winnowing bottom currents or less probably low-density turbidity currents. Thus, indicators show that almost all of the Lowermost Cretaceous at this site is at least redeposited.

\section{Site 766 in the Gascoyne Abyssal Plain}

Site 766 is located at the base of the steep western margin of the Exmouth Plateau (Figs. 1A, 1B). The oldest sediment penetrated is uppermost Valanginian sandstone and siltstone, which is interbedded with inclined basaltic sills.

The uppermost sediment/basalt interface occurs in Section 123-766A-48R-6 at $129 \mathrm{~cm}$ ( $460.6 \mathrm{~m}$ below seafloor [bsf]). Site 766 appears to have remained above or near the CCD throughout its history.

A total of $466.7 \mathrm{~m}$ of Pleistocene to upper Valanginian or Hauterivian sediments was cored at Site 766. The dominant lithologies in the lowermost part of the sedimentary column (uppermost Valanginian to Hauterivian) are dark greenish gray silty sandstones and sandy siltstones having well-rounded glauconite grains and echinoderm fragments, altered volcaniclastic grains, as well as quartz sand and silt. Clay-size material is rare. Normal grading is the most common sedimentary structure within the coarser-grained lithologies; reverse grading and complex grading also occur. Mottling and burrowing are common within finergrained intervals. The sequence constitutes a wedge of redeposited shallow marine sediment that thickens eastward toward the Exmouth Plateau and southward toward the Cuvier Abyssal Plain. Coarsening-upward of the sequence as a whole indicates progradation of a submarine fan composed of sediment derived from the adjacent Exmouth Plateau. Thin, waxy noncalcareous clay laminae in the lower part-especially in Core 123-766A-48R - are interpreted as bentonitic claystones. 
Table 2 (continued).

\begin{tabular}{|c|c|c|c|c|c|c|c|c|c|c|c|c|c|}
\hline $\begin{array}{l}\text { Core, section, } \\
\text { interval }(\mathrm{cm})\end{array}$ & $\begin{array}{r}\mathrm{P}_{2} \mathrm{O}_{5} \\
(\%)\end{array}$ & $\begin{array}{l}\mathrm{SO}_{3} \\
(\%)\end{array}$ & $\underset{(\mathrm{ppm})}{\mathrm{Ba}}$ & $\underset{(\mathrm{ppm})}{\mathrm{Ce}}$ & $\underset{(\mathrm{ppm})}{\mathrm{Cr}}$ & $\begin{array}{c}\mathrm{Nb} \\
(\mathrm{ppm})\end{array}$ & $\underset{(\mathrm{ppm})}{\mathrm{Ni}}$ & $\begin{array}{c}\mathrm{Pb} \\
(\mathrm{ppm})\end{array}$ & $\begin{array}{c}\mathrm{Rb} \\
(\mathrm{ppm})\end{array}$ & $\underset{(\mathrm{ppm})}{\mathrm{Sr}}$ & $\begin{array}{l}\text { Th } \\
\text { (ppm) }\end{array}$ & $\underset{(\mathrm{ppm})}{\mathrm{V}}$ & $\begin{array}{c}\mathrm{Y} \\
\text { (ppm) }\end{array}$ \\
\hline $122-761$ B-29X-CC, $25-27$ & 0.04 & 0.05 & 50 & 56 & 19 & 12 & 27 & 32 & 12 & 51 & 13 & 27 & $<5$ \\
\hline $122-761 \mathrm{C}-7 \mathrm{R}-1,63-65$ & 0.05 & 0.16 & 286 & 107 & 66 & 22 & 57 & 178 & 24 & 57 & 25 & 47 & $<5$ \\
\hline $8 \mathrm{R}-1,131-133$ & 0.04 & 0.05 & 69 & 37 & 27 & 12 & 22 & 43 & 8 & 32 & $<1$ & $<1$ & $<5$ \\
\hline $8 \mathrm{R}-2,21-23$ & 0.05 & 0.07 & 793 & $<35$ & 16 & 10 & 52 & 28 & 21 & 77 & $<1$ & 29 & $<5$ \\
\hline $9 R-2,18-19$ & 0.04 & 0.08 & 62 & 174 & 15 & 15 & 29 & 24 & 15 & 21 & 59 & $<1$ & 36 \\
\hline 9R-CC, 7-9 & 0.09 & 0.08 & 450 & 146 & 38 & 26 & 81 & 101 & 91 & 83 & 10 & 61 & 7 \\
\hline $10 \mathrm{R}-1,18-19$ & 0.05 & 0.04 & 604 & 208 & 10 & 21 & 80 & 23 & 13 & 70 & 27 & 20 & 77 \\
\hline $10 \mathrm{R}-1,35-37$ & 0.05 & 0.11 & 57 & 269 & 27 & 30 & 21 & 29 & 22 & 15 & 48 & 15 & 26 \\
\hline $123-765 C-58 R-5,99-101$ & 0.06 & 0.15 & 2822 & $<35$ & 70 & 12 & 46 & 26 & 49 & 98 & $<1$ & 98 & 15 \\
\hline $59 \mathrm{R}-3,94-96$ & 0.21 & 0.52 & 6463 & 401 & 65 & 72 & 43 & 125 & 40 & 583 & 27 & 22 & 84 \\
\hline $60 \mathrm{R}-1,84-86$ & 0.21 & 0.11 & 1394 & 123 & 103 & 14 & 88 & 34 & 104 & 107 & 13 & 93 & 32 \\
\hline $60 \mathrm{R}-1,112-115$ & 0.29 & 0.14 & 1659 & 131 & 57 & 12 & 57 & 26 & 81 & 98 & $<1$ & 45 & 35 \\
\hline $60 \mathrm{R}-1,120-123$ & 0.39 & 0.23 & 3374 & 178 & 78 & 11 & 67 & 16 & 81 & 136 & $<1$ & 81 & 45 \\
\hline $60 \mathrm{R}-3,16-20$ & 0.13 & 0.17 & 1748 & 96 & 104 & 14 & 206 & 47 & 93 & 105 & $<1$ & 458 & 22 \\
\hline $60 \mathrm{R}-3,61-64$ & 0.03 & 0.18 & 1783 & $<35$ & 59 & 16 & 178 & 33 & 21 & 152 & 26 & 3100 & 13 \\
\hline $60 R-4,32-36$ & 0.32 & 0.14 & 1945 & 162 & 68 & 14 & 76 & 32 & 92 & 102 & $<1$ & 71 & 39 \\
\hline $60 R-5,61-64$ & 0.06 & 0.05 & 439 & 41 & 16 & 16 & 136 & 12 & 26 & 116 & 16 & 2291 & 20 \\
\hline $60 R-5,116-119$ & 0.04 & 0.18 & 258 & 47 & 100 & 20 & 142 & 29 & 20 & 63 & $<1$ & 323 & 11 \\
\hline $60 \mathrm{R}-5,116-119$ & 0.05 & 0.10 & 511 & 41 & 75 & 13 & 230 & 221 & 15 & 128 & $<1$ & 985 & $<5$ \\
\hline $60 \mathrm{R}-5,120-123$ & 0.04 & 0.10 & 53 & $<35$ & $<7$ & 12 & 143 & 33 & $<5$ & 116 & $<1$ & 423 & $<5$ \\
\hline $61 R-1,33-36$ & 0.13 & 0.17 & 3093 & 155 & 82 & 22 & 77 & 50 & 90 & 127 & 14 & 56 & 29 \\
\hline $61 R-1,50-52$ & 0.20 & 0.10 & 890 & 184 & 71 & 26 & 72 & 35 & 57 & 117 & 23 & 40 & 52 \\
\hline $61 R-1,61-64$ & 0.06 & 0.18 & 384 & 51 & 40 & 12 & 143 & 25 & 14 & 107 & 21 & 108 & 16 \\
\hline $61 \mathrm{R}-1,61-64$ & 0.02 & 0.04 & 96 & $<35$ & 35 & 24 & 83 & 14 & 9 & 54 & 24 & 104 & 9 \\
\hline $61 R-2,52-56$ & 0.15 & 0.09 & 326 & 70 & 75 & 20 & 67 & 45 & 58 & 75 & 18 & 60 & 22 \\
\hline $61 R-4,71-74$ & 0.15 & 0.08 & 468 & 602 & 19 & 51 & 97 & 24 & 53 & 124 & 21 & 106 & 86 \\
\hline $61 \mathrm{R}-4,79-82$ & 0.17 & 0.18 & 90 & 123 & 21 & 65 & 111 & 39 & 39 & 112 & 16 & 33 & 50 \\
\hline $61 \mathrm{R}-4,79-82$ & 0.15 & 0.16 & 68 & 89 & 23 & 63 & 196 & 39 & 37 & 111 & 21 & 450 & 52 \\
\hline $61 R-4,79-82$ & 0.12 & 0.10 & 85 & 129 & 17 & 67 & 220 & 19 & 36 & 114 & 25 & 571 & 46 \\
\hline $61 R-4,79-82$ & 0.13 & 0.15 & 149 & 86 & 17 & 68 & 101 & 24 & 38 & 102 & 19 & 32 & 42 \\
\hline $123-766 \mathrm{~A}-48 \mathrm{R}-2,142-147$ & 0.06 & 0.22 & 99 & 224 & 14 & 60 & 29 & 38 & 7 & 127 & 63 & $<1$ & 55 \\
\hline $48 \mathrm{R}-2,142-147$ & 0.05 & 0.47 & 61 & 172 & 13 & 58 & 23 & 65 & 10 & 139 & 55 & $<1$ & 47 \\
\hline $48 \mathrm{R}-4,78-81$ & 0.09 & 0.92 & 334 & 202 & 33 & 57 & 47 & 58 & 32 & 140 & 25 & 34 & 80 \\
\hline
\end{tabular}

Table 3. DSDP sites in the vicinity of Legs $122 / 123$ and oldest sediments recovered (compare with Fig. 1C).

\begin{tabular}{|c|c|}
\hline Site & Age \\
\hline 211 & Campanian (nannofossil clay), above basement \\
\hline 212 & middle-Upper Cretaceous (zeolitic clay), above basement \\
\hline 256 & Late Cretaceous (brown detrital clay), above basement \\
\hline 257 & Albian (nannofossil-detrital clay and clayey chalk), above basement \\
\hline 258 & $\begin{array}{l}\text { Albian with glauconitic sand at the base (comparable to the lower part of } \\
\text { Hole } 766 \mathrm{~A} \text { ) }\end{array}$ \\
\hline 259 & Aptian (green-gray claystone), above basement \\
\hline 260 & Albian (radiolarian and nannofossil ooze), above basement \\
\hline 261 & $\begin{array}{l}\text { Oxfordian to Tithonian (brown nannofossil-rich claystone), above } \\
\text { basement }\end{array}$ \\
\hline 262 & Pliocene \\
\hline 263 & $\begin{array}{l}\text { Albian (or older, but younger than Berriasian/Valanginian; quartz-bearing } \\
\text { clay), resembles lower part of Hole } 766 \mathrm{~A}\end{array}$ \\
\hline
\end{tabular}

The age of the uppermost bentonites at Site 766 is roughly the same as those at Site 765 , although their lithological characteristics are somewhat different. The interval consists predominantly of greenish-gray claystone containing abundant silt- to sand-size glauconite(?) and as much as $50 \%$ radiolarians. Common coarser-grained intercalations consist predominantly of glauconite(?), quartz, calcite, and bioclasts. This facies apparently signals redirection of the coarse sediment away from Site 766, or an abandoning of the progradational wedge system, possibly related to the late Hauterivian to Barremian highstand in sea level. The section above is roughly equivalent to an unconformity on the Exmouth Plateau. Berriasian to lower Valanginian prodeltaic sediments of the Barrow Group, at Sites 762 and 763 on the Exmouth Plateau (von Rad, Haq, et al., 1992) are overlain by Aptian carbonates. A likely source of sediment for this interval is shallow marine and volcaniclastic material from the outer margin of the Exmouth Plateau, presumably having been transported off the plateau during the lower Valanginian to Aptian hiatus.

\section{Site 761 on the Wombat Plateau}

Drilling at Site 761 on the Wombat Plateau, a small subplateau of the northern Exmouth Plateau (Fig. 2), penetrated a very thin $(<30 \mathrm{~m})$ "juvenile ocean" section of terrigenous to hemipelagic sediments overlying a marked "post-rift unconformity." The sequence contains the following:

1. A 5-m-thick, upward-fining (i.e., upward-deepening) condensed section of ferruginous sand that grades into a belemniterich sandy silt/clay. This sequence has been interpreted as a transgressive ([?]littoral to nearshore) sand that was deposited under high-energy conditions and a reworking of the upper Triassic siliciclastic sediments exposed in the area of Site 760 on the uplifted Wombat block. The belemnite sandy silt/clay was deposited in a low-energy, outer-shelf setting at very low sedimentation rates. This sequence is roughly similar to the Birdrong Sandstone of the Carnarvon Basin (Hocking et al., 1987). This formation, although somewhat younger (Valanginian to Barremian), is a coastal to nearshore, diachronous deposit of a few tens of meters that formed during the Neocomian transgression.

2. A 25 -m-thick section dominated by hemipelagic calcisphere nannofossil chalks and marls, intercalated with porcellanite nodule horizons ( $240-246 \mathrm{mbsf}$ ) and (at least) six conspicuous bentonite horizons, named B1 through B6. The water depth during this interval increased by rapid early post-breakup subsidence to bathyal depths (about 200-1000 m). This sequence might correlate with the Muderong Shale (Valanginian to Aptian), a partly restricted, low-energy offshore marine deposit of the Carnarvon 


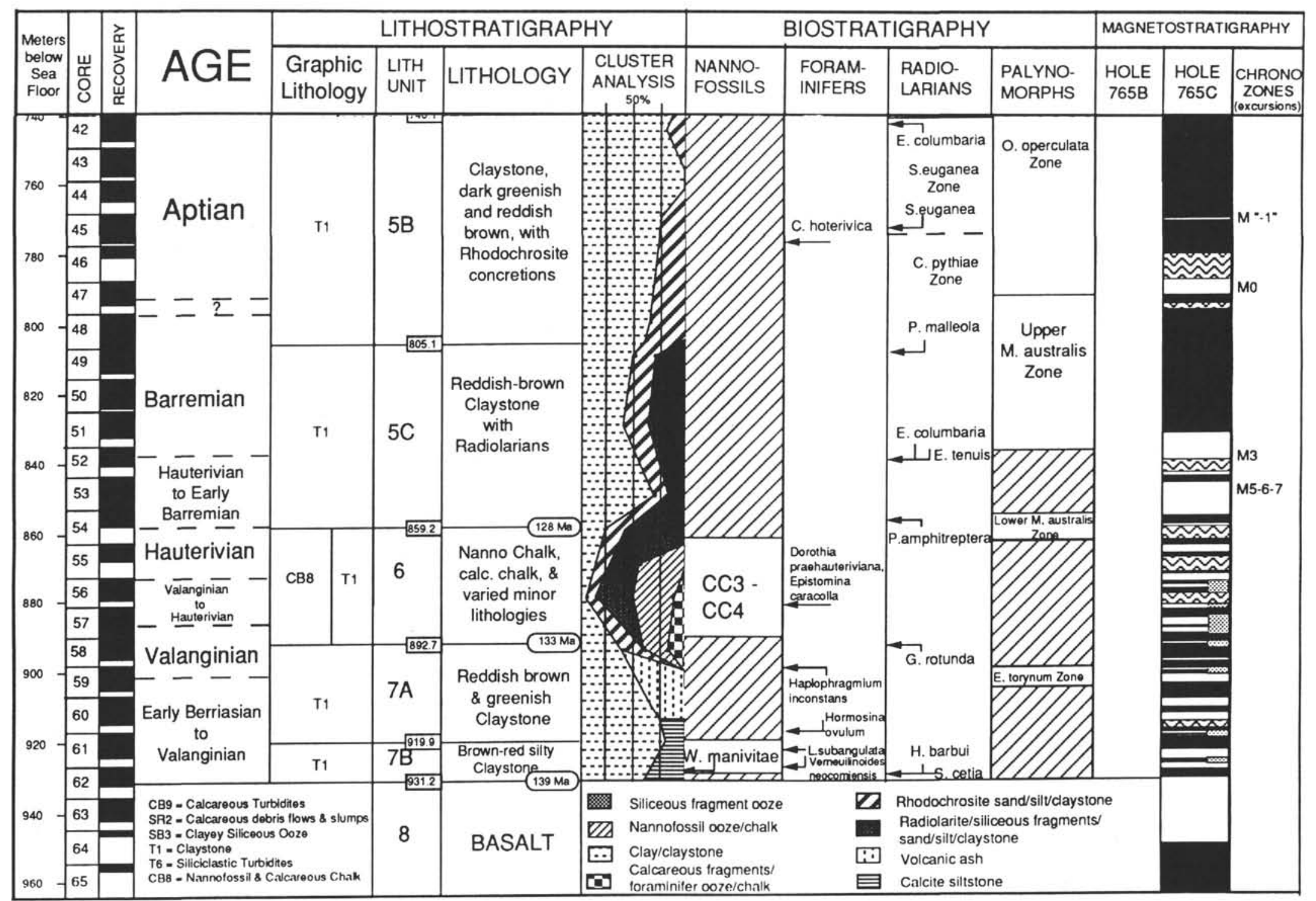

Figure 4. Compilation of lithostratigraphic, biostratigraphic, and magnetostratigraphic data for Site 765 (Ludden, Gradstein, et al., 1990). 
Basin (Hocking et al., 1987). The porcellanite horizons might be partly equivalents of the Windalia Radiolarite, although no Aptian age was established at Site 761.

3. Above about $234 \mathrm{mbsf}$, eupelagic nannofossil chalks, deposited in a water depth of about $1000 \mathrm{~m}$, were recovered ("mature ocean phase").

\section{Site 763}

In Site 763 on the southwestern Exmouth Plateau, we discovered only bentonitic claystones in Samples 122-763C-29R-4, $102-104 \mathrm{~cm}$, and $-26 \mathrm{R}-4,28-30 \mathrm{~cm}$. Drilling at Site 763 penetrated a 414-m-thick "syn-rift" section of shelf-margin prodelta origin (Haq, von Rad, O'Connell, et al., 1990). Sample 122-763C$29 \mathrm{R}-4,102-104 \mathrm{~cm}$, is from a 7-cm-thick, dark bluish-gray $(5 \mathrm{~B} 4 / 1)$ bentonite layer in a very dark gray, middle-to-upper Berriasian silty claystone section. Sample 122-763C-26R-4, 128$131 \mathrm{~cm}$, is a montmorillonitic claystone layer, also intercalated in a very dark gray silty claystone sequence of middle-to-late Berriasian age.

\section{AGE OF BENTONITIC CLAYSTONES}

\section{Site 765}

Figure 4 is a compilation of all stratigraphic data obtained for the basal part of Site 765. Based on nannofossil data from the calcareous intervals (distal turbidites[?] with no identification of floral/faunal mixing), we can ascribe a Berriasian/Valanginian age to the fauna. Radiolarians from autochthonous intervals indicate a Berriasian age. The autochthonous benthic fauna confirms - with lesser precision-this age assignment.

\section{Site 761}

The biostratigraphic age of the section (including the bentonites) is poorly constrained: unambiguous nannofossil age determinations are from Section 122-761C-7H-1, $100 \mathrm{~cm}$ ("late Berriasian-early Valanginian,") and from Sample 122-761C-7R-1, 31-34 cm (Calcicalathina oblongata Zone, CC3, late Valanginian; P. Cěpek, pers. comm., 1991). All samples from Cores 122-761C-8R, -9R, and -10R proved to be "late Kimmeridgian to late Valanginian" in age (P. Cěpek, pers. comm., 1991). The belemnites belong to the species Belemnopsis, which in the IndoPacific realm has a range from Tithonian up to the Valanginian (J. Mutterlose, pers. comm., 1991). Section 122-761C-6H-CC contains Albian radiolarians in a porcellanite and Section 122761B-28R-CC, an early to middle Albian nannoflora, whereas Sample 122-761C-5H-2, 139-141 cm, has a Cenomanian age (Eiffellithus turriseiffeli Zone [CC9-top]/Microrhabdus decoratus Zone [CC10]; P. Cěpek, pers. comm., 1991).

Tentatively, we have assumed a ([?]Tithonian) to Berriasian age for the basal (belemnite) sand (257-262 mbsf) and a late Berriasian to late Valanginian age for the section between 240 and $257 \mathrm{mbsf}$ that contains the bentonites B1 through B6. This section is obviously condensed and might contain a number of hidden smaller hiatuses, although we did not observe any phosphatic or manganese horizons.

\section{Site 766}

The age of the waxy bentonitic claystones in Site 766 is comparable to, but younger than, (Valanginian/Hauterivian based on nannofossil biomarkers) that of the bentonites in Site 765; however, the ages determined in Site 766 are not as reliable as those in Sites 761 and 765.

\section{REGIONAL CORRELATIONS}

A survey of DSDP sites in the vicinity of Legs 122/123 (Fig. 1C and Table 3 ) revealed only one site (Leg 27, Site 261, Argo
Abyssal Plain) having sediments old enough to contain bentonites in a comparable stratigraphic position to Sites $761,763,765$, and 766. Lower Cretaceous sediments of Unit 4 (Shipboard Scientific Party, 1974) are semilithified, intermittently calcareous brown claystone. In Sample 261-31-2, 48-56 cm, the brownish to reddish background sedimentation has been interrupted by a distinct light gray layer of smectitic claystone having a minor amount of quartz (bulk sample: $98 \%$ smectite, $2 \%$ quartz; shipboard data). The base of the interval is sharp and marked by a thin layer $(2 \mathrm{~mm})$ of gray-green claystone on top of the underlying reddish-brownish claystone. The upper contact is gradual, and a transition from light gray to reddish and, finally, to brownish occurs. The interval between 50 and $53 \mathrm{~cm}$ exhibits mottling of light gray and reddish clay. The light gray and reddish claystones have a characteristic soapy or waxy appearance. Sedimentary structures are not visible. According to shipboard data, the age of this interval is Berriasian or Valanginian, and thus is in good accordance with the age of the bentonite layers found in Leg 122/123 sites. In Sample 261-29-2, $25-50 \mathrm{~cm}$, an interval of unusually colored claystones is intercalated in the brownish background sediments. Again, these varicolored claystones have a characteristic soapy or waxy appearance. According to shipboard data, this interval is Valanginian in age. No more data can be obtained because both intervals have been sampled almost completely.

In the Carnarvon Basin (southwest of the Exmouth Plateau), bentonitic sequences (tuffs, etc.) are intercalated in the argillaceous siltstones of the Muderong Shale (Valanginian to Aptian) and of the Gearle Siltstone (Albian to Turonian) (see Hocking et al., 1987). The latter occurrence is clearly younger than our bentonites, while the former might have the same age.

\section{ASSOCIATION OF SEDIMENTARY FABRIC AND FACIES OF BENTONITE LAYERS}

\section{Argo Abyssal Plain Bentonites}

Discrimination of bentonites from the Argo Abyssal Plain bentonites is not as easy as, for example, those on the Wombat Plateau. Despite the distinct color difference compared to the surrounding sediment, clay mineralogy spectra and sediment geochemistry of the bentonites are similar to the background sedimentation. Such a finding may suggest that the major part of the generally reddish to brownish background sediments of the lower part of the Site 765 sedimentary sequence also has a volcanic origin.

Pure "bentonites" are discriminated from the background sediments by the clay mineral composition (pure smectite with a distinct fabric); the occurrence of biotite; ilmenite, "bubble" glass shards; the enrichment of barite, apatite, and zircon in the heavy mineral spectrum; and the absence of any debris in the central parts of the sediments.

Basal parts of bentonitic claystones (which are interpreted as having been redeposited often) contain fossil debris. This debris is in the form of either fragments of agglutinating foraminifers or silt-size quartz sand. This sand derives from the disintegration of the agglutinating foraminifers tests. It is not clear whether this debris was taken up during transport of the ash material or was covering the seafloor and was buried by ash material.

The common occurrence of barite (a mineral that certainly is not of volcanic origin at this site) may be related to particular chemical conditions at the boundary between a bentonite and the underlying sediment.

According to visual appearance, we were able to distinguish four types of smectite-rich bentonites as follows:

1. Type 1 is whitish/light gray to light greenish-gray smectitic claystones of characteristic soapy or waxy appearance and thick- 
nesses of 5 to $14 \mathrm{~cm}$ (Pl. 1, Fig. 1). The lower contact is sharp, while the upper contact is gradual (Pl. 1, Fig. 2), indicating a sedimentary, rather than a fall-out, origin for these bentonites. Distinct intervals occur in intervals $123-765 \mathrm{C}-60 \mathrm{R}-5,112-125$ $\mathrm{cm}$; $-61 \mathrm{R}-1,58-63 \mathrm{~cm}$; and $-61 \mathrm{R}-4,77-91 \mathrm{~cm}$.

2 . Type 2 is greenish-gray smectitic claystones of characteristic soapy or waxy appearance and thicknesses of up to $3 \mathrm{~cm}$. The upper and lower contact is always sharp (PI. 1, Fig. 3). Distinct intervals occur in Samples 123-765C-61R-1, 89-92 cm; $-61 \mathrm{R}-1,99-101 \mathrm{~cm}$; -61R-1, 104-107 cm; -61R-1, 115-118 cm; and $-62 \mathrm{R}-1,58-61 \mathrm{~cm}$.

3. Type 3 is whitish or gray-green smectitic claystones of characteristic soapy or waxy appearance and thicknesses of up to $8 \mathrm{~cm}$. These intervals have a slightly mottled appearance, and their contacts are not sharp. Distinct intervals occur in Samples 123765C-60R-5, 58-64 cm; -61R-1, 0-8 cm; and -61R-3, 15-22 cm. All these bentonites might belong to Type 1 , but their original appearance has been destroyed, either by bioturbation or by redeposition. Thin stringers of Type 3 (Pl. 1, Fig. 3) are mottled with reddish-brownish background claystone throughout Samples 123-765C-58R-4, 110-140 cm; -58R-5, 60-140 cm; and Sections 123-765C-60R-4 and -60R-5 (Pl. 1, Fig. 4). Again, their origin might be the result of redeposition or of bioturbation.

4. Type 4 includes all smectitic claystones that are doubtful bentonites. Principally, these are intense brick- to dark-red, smectite-rich claystones of characteristic soapy or waxy appearance. In general, their contacts are diffuse (PI. 1, Figs. 5 and 6). Typical intervals are 123-765C-57R-7, 7-10 cm (above a gray waxy smectitic claystone); and $-58 \mathrm{R}-2,136-137 \mathrm{~cm}$. In interval $123-$ $765 \mathrm{C}-59 \mathrm{R}-4,125-150 \mathrm{~cm}$, a varicolored waxy interval of smectitic claystone occurs (Type 4; Pl. 1, Fig. 4) comparable to those described from DSDP Site 261, Core 29-2, 25-50 cm.

\section{Wombat Plateau Bentonites at Site $\mathbf{7 6 1}$}

The bentonites (B1 through B6) are subdivided by color, fabric, and composition into two distinctive groups: (1) white, pink, and light gray, pure smectite bentonites (B1, B3, and B5) with a "waxy" appearance, usually grading upward into slightly darker colors (light gray, pale yellow) with distinct lower and gradational upper contacts; and (2) (dark) gray to brown, impure silty bentonitic claystones (B2, B4). All bentonites have gradual contacts to the overlying nannofossil chalk (background sedimentation). A brown silty clay/marlstone at $237 \mathrm{mbsf}$ might be another bentonite (B7[?]). The thickness of the bentonites varies between 0.1 and $0.7 \mathrm{~m}$; thus, these bentonites are considerably thicker than those found at Site 765. A detailed description was presented by von Rad and Thurow (1992).

\section{COMPOSITION AND FINE STRUCTURE OF BENTONITIC LAYERS}

\section{Mineralogical Composition}

The bentonites can be classified into two major groups: pure smectite bentonite and impure bentonitic claystones and are described as follows:

1. Pure (white to gray/red) smectite bentonites characterized by a homogeneous, cryptocrystalline matrix of pure montmorillonite $(>95 \% \rightarrow>99 \%$; Pl. 2, Figs. 2,3$)$ that exhibits a typical pinpoint extinction under crossed nicols. XRD analysis proves that the rocks are essentially carbonate-free and contain extremely well-ordered, mainly dioctaedric smectite as the only clay mineral. A "vitroclastic fabric" is produced by small $(10-20 \mu \mathrm{m})$, flat, partly V-shaped glass shards that have been replaced by smectite (Pl. 3, Figs. 1, 3). SEM photomicrographs show the typical "honeycomb texture" of smectite blades, partly in spherical aggregates of about $5 \mu \mathrm{m}$ in diameter, with a regular, open honeycomb texture (Kon̆ta, 1986; Pl. 2, Figs. 1, 6; Pl. 3, Figs. 5, 6). Almost all intraclasts are overgrown or have been replaced by smectite (Pl. 3, Figs. 2, 3). Exceptions are a few terrigenous quartz crystals (2-10 $\mu \mathrm{m})$ and feldspar (plagioclase and K-feldspar (Pl. 4, Fig. 16) grains, and trace amounts of clinoptilolite, "glauconite-type" phyllosilicates and calcispheres (PI. 2, Fig. 7). Some bentonites also contain idiomorphic to rounded quartz (Pl. 4, Figs. 1-3), bubble-wall glass shards (Pl. 4, Figs. 4-7), ilmenite (Pl. 4, Figs. $8-10$ ), and copper minerals (Pl. 4, Fig. 11). Heavy minerals are dominated by apatite (Pl. 2, Figs. 4, 5; Pl. 4, Fig. 14), barite (Pl. 4, fig 15), zircon (Pl. 4, Figs. 12,13), and idiomorphic biotite.

Chemically, the pure smectite bentonites approach the average composition of smectite (Table 2). The average loss on ignition (LOI; $\mathrm{H}_{2} \mathrm{O}$ content), calculated in percentage of total sample, is about $17 \%$.

2. Impure (dark gray to reddish-brown) silty or mottled bentonitic claystones often with a slight amount of illite (PI. 3, Fig. 4) are more heterogeneous than the impure bentonites because the upper parts of the impure bentonites are mixed with the overlying calcisphere chalks by bioturbation, or because they were originally deposited as more heterogeneous claystones. Usually, they are more silty (to sandy), mottled, and contain smectite as the main clay mineral, in addition to trace amounts of illite. The smectite in these claystones is mixed with a great variety of pelagic (biogenic), terrigenous, volcanic, and authigenic components.

Biogenic components consist of calcispheres (often smectitefilled), coccoliths, mollusk fragments, sponge spicules, and recrystallized radiolarians. Of terrigenous origin are silt-sized quartz $(10-50 \mu \mathrm{m})$, feldspar (especially plagioclase), biotite (especially abundant in Site 763), garnet (Site 763), tourmaline, titanite, and, in part, zircon (rounded varieties).

Of special interest for the origin of these bentonitic claystones are volcaniclastic grains. These include (1) altered, often ferruginized, volcanic rock fragments (Sites 761, 766); (2) colorless, more or less, fresh bubble-wall and coniform glass shards, which may be slightly to completely altered to smectite; and (3) euhedral sanidine crystals. In particular, bentonite B3 (and B2) in Site 761, and Sample 123-765C-61 R-1, 61-64 cm, are rich in glass shards. We measured a refractive index of $n=1.485$ to 1.495 in the freshest-looking shards that correlates with a highly silicic (rhyolitic) composition of $>70 \% \mathrm{SiO}_{2}$; (Huber and Rinehart, 1966; von Rad and Mühe, 1990). However, the refractive index has probably been lowered by the partial hydration and zeolitization of these glass shards. EDX analysis also indicates a Si- and $\mathrm{K}$-rich, rhyolitic composition. Other glass shards have been completely replaced by clinoptilolite. Other volcanic-derived minerals include clinopyroxene (B2) and the apatite- and zircon-dominated heavy mineral assemblages. In particular, apatite and slender, long-prismatic zircon often have been interpreted as indicating a volcanic source rock (Zimmerle and Gaida, 1980; Pupin, 1980; Winkler et al., 1985; Zimmerle, 1989).

Authigenic components include glauconite (reworked from associated hemipelagic sediments), authigenic clinoptilolite (derived from silica diagenesis of volcanic glass and skeletal opal), reworked dolomite, and pyrite (diagenesis of organic matter, especially in Site 763). Geochemically, the impure bentonitic claystones in Site 761 are low in $\mathrm{SiO}_{2}(48 \%-55.5 \%)$, high in $\mathrm{TiO}_{2}$ $\left(0.29 \%-1.8 \%\right.$ !), low in $\mathrm{Al}_{2} \mathrm{O}_{3}(<15 \%)$, high in $\mathrm{Fe}_{2} \mathrm{O}_{3}(>3.3 \%$, up to $9.8 \%$ in brown claystones), high in $\mathrm{CaO}$ ( $>1 \%$, calcispheres, coccoliths), high in $\mathrm{K}_{2} \mathrm{O}(>0.6 \%-2.15 \%$, volcanic glass, $\mathrm{K}$-feldspar), very high in $\mathrm{Ba}(>280 \mathrm{ppm})$, high in $\mathrm{Sr}(>50 \mathrm{ppm})$, and high in V (>20 ppm). Impure bentonites in Site 765 are not exceptionally different from the pure varieties, and no trends of enrichment/depletion of the various oxides were observed. 
The lowermost clay assemblage at Site 765 (from 912 to 610 mbsf) is predominantly smectite, with illite constituting from $0 \%$ to $50 \%$ of the sample. Diagenetic micro- to cryptocrystalline quartz is abundant below $744.3 \mathrm{mbsf}$, especially in the $<2 \mu \mathrm{m}$ size fraction.

\section{Origin of the Clay Minerals}

We interpreted illite as terrigenous at Site 765 , because the sediment has not been buried deeply enough to form illite by alteration of smectite, as observed in deeply buried sediments from the U.S. Gulf Coast region. Smectite is abundant. This smectite is either terrigenous or an alteration product of volcanic and terrigenous material. Sediment layers composed of nearly $100 \%$ smectite have been interpreted as altered volcanic ash deposits. The abundance of smectite in the lowermost clay assemblage and its high $\mathrm{Fe}$ and $\mathrm{Mg}$ content suggest that a significant amount was derived from the alteration of mafic volcanic material, which conflicts with the results obtained from the glass shards (see above).

In the lowermost part of Hole $765 \mathrm{C}$, smectite dominates illite, while other clay minerals are missing (traces of kaolinite were found in turbidites). A distinct amount of opal and diagenetic quartz also was observed. Figure 3 presents an overview of the distribution of clay minerals in the lowermost part of the sedimentary column at Site 765 (shipboard data; the illite content has been overestimated). Smectite dominates the clay mineral pattern in all Lower Cretaceous samples, and its occurrence is independent of sediment color or type. Although most likely the source of the smectite can be found in volcanic rocks of basement highs that crop out in the vicinity of Site 765 , the large volume of smectite required to form the Lower Cretaceous sedimentary cover of the Argo Abyssal Plain suggests an alterative explanation for the dark reddish or brownish claystones. One such explanation might be the formation of smectite by alteration of detrital illite (which would provide the necessary aluminium) and dissolution of radiolarian tests.

\section{Bentonitic Claystones}

XRD analyses of the $<2-\mu \mathrm{m}$ fraction were performed to compare clay mineral spectra of the four defined types of bentonite (i.e., Samples 123-765C-60-1, 84-86 cm, dark brick-red, Type 4; $-765 \mathrm{C}-60 \mathrm{R}-4,32-36 \mathrm{~cm}$, mottled, Type 3; transitional zone between Type 1 bentonite and background sedimentation; -765C$61 \mathrm{R}-4,71-74 \mathrm{~cm}$, upper part: brownish waxy claystone; $-765 \mathrm{C}$ $61 \mathrm{R}-4,71-74 \mathrm{~cm}$, lower part: brick-red waxy claystone, upper part of Type 1 bentonite, mottled brick-red/light-gray; -765C$61 \mathrm{R}-4,79-82 \mathrm{~cm}$, brick-red; $-765 \mathrm{C}-61 \mathrm{R}-4,79-82 \mathrm{~cm}$, light gray.

In addition to the dominance of smectite, the samples of Types 3 and 4 show a small, but distinct, peak of illite (less than $5 \%$ of the clay fraction) and thus resemble the analysis of the background claystone (as shown in Fig. 4). Type 2 bentonites are pure smectites (shipboard data). The transitional zone of Type 1 bentonite to the background sediments (Samples 123-765C-61R-4, $71-74 \mathrm{~cm}$ ) may still contain rare illite, but no more distinct peaks occur. Smectite is the only clay mineral found in Type 1 bentonites (Samples 123-765C-61R-4, 79--82 cm (light gray). Because the red part in Sample 123-765C-61R-4, 79-82 cm, indicates an identical XRD pattern when compared with the light-gray part, the higher Fe content (which led to the brick-red color; compare with Table 2) may be of secondary origin.

XRD analyses support the idea that bentonites of Types 1 and 2 are virtually altered ash layers, while bentonites of Types 3 and 4 are mixtures of bentonitic claystones and background claystones. These findings are similar to those observed for the Leg 122 bentonites (von Rad and Thurow, 1992). At Site 766 (Gascoyne Abyssal Plain), all smectite-rich layers having a waxy appearance were reported to be fine, detrital, volcaniclastic layers (Pl. 2, Fig. 8). Two XRD analyses of the $<2-\mu \mathrm{m}$ fraction (Samples 123-766A-45R-6, 45-50 cm; -766A-48R-4, 78-81 cm) showed that even these intervals consist of pure smectite.

To identify the type of smectite that formed these bentonites, we analyzed three pure bentonites from Sites 761 and 765 at the AWI in Bremerhaven (Fig. 5; R. Petschik, analyst, CoK $\alpha$ ).

All three samples (123-761C-9H-2, 18-19 cm; -761C-10H-1, $36-37 \mathrm{~cm},-765 \mathrm{C}-61 \mathrm{R}-1,61-64 \mathrm{~cm}$ ) are pure dioctahedral (A13+ dominating) smectite with minor amounts of opal. This smectite shows basal (001)-reflections equivalent to a $12 \AA$-mineral, which has been named in the literature, Na-montmorillonite (a better name would be $\mathrm{Na}$-smectite). Sedimentary smectite usually shows basal reflections of about 14 to $15 \AA$ ( $\mathrm{Mg} / \mathrm{Al}$-smectite). An explanation might be the disappearance of $\mathrm{Ca}$ and subsequent enrich-

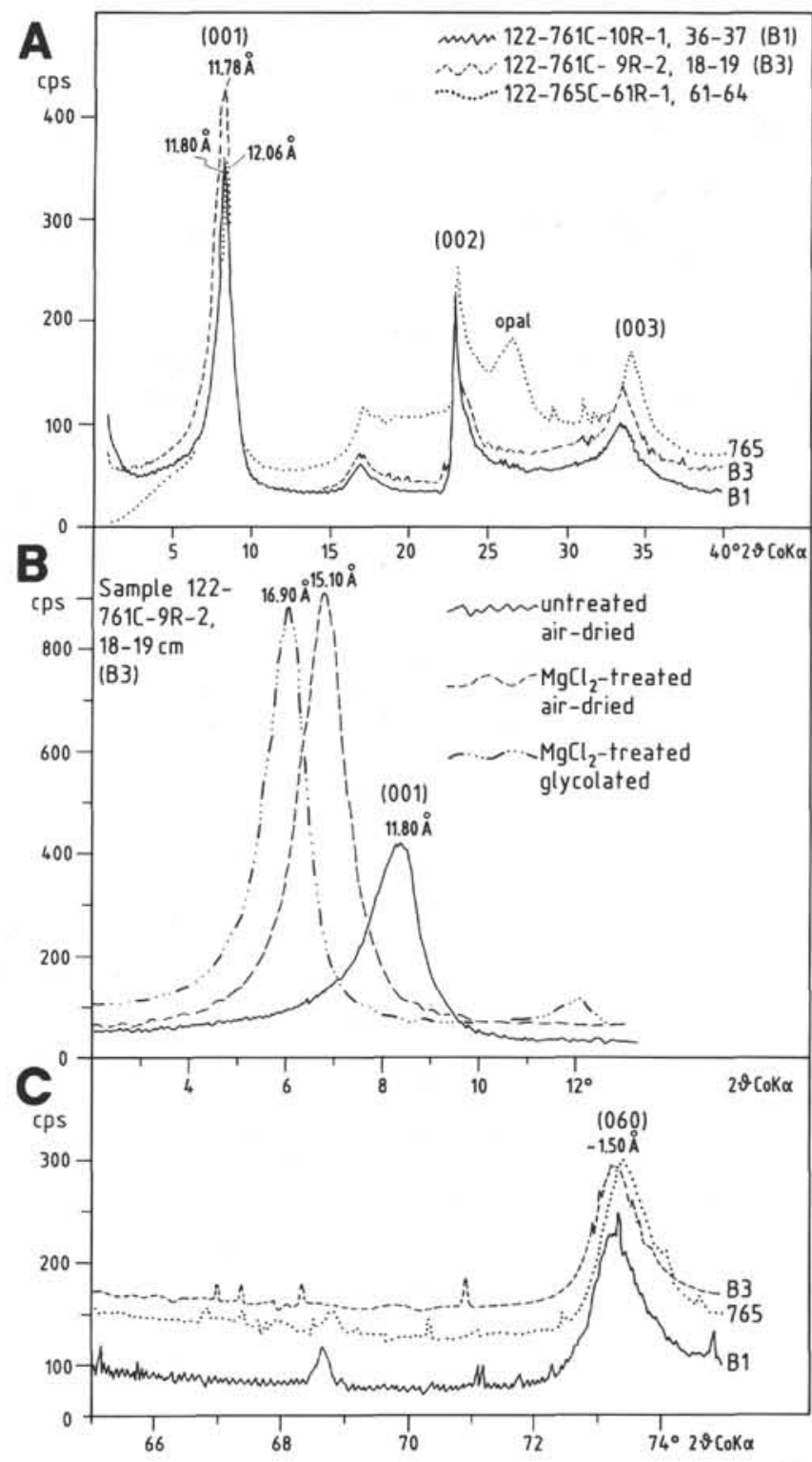

Figure 5. A. X-ray diffractograms of three untreated bentonite samples. Intensity in counts per second (cps). Note that the base reflex (001) is almost identical for all three samples. B. (001) base line of smectite of Sample 122-761C-9R-2, 18-19 cm, for different sample preparations. C. (060) reflexes of smectite for the same samples as in A. 
ment of Na during the alteration of volcanic glass. This hypothesis is supported by the relatively high $\mathrm{Na}$-values of the samples (Table 2). Such smectites have been recorded from ash layers in the northern calcareous Alps (R. Petschik, written comm., 1991).

\section{Sediment Inorganic Geochemistry}

\section{Sediment Geochemistry (XRF Elemental Analyses)}

We analyzed all types of bentonitic claystones (pure and impure) to discover the chemical composition of the ash layers, their rock classification, and the type of volcanism related to formation of large amounts of ash in the Lowermost Cretaceous off northwestern Australia. For comparison, we analyzed bulk samples and the $<2-\mu \mathrm{m}$ fraction from selected samples, as well as whitish and red parts of pure bentonites. No significant differences were observed between bulk samples and the $<2-\mu \mathrm{m}$ fraction, suggesting that the detrital component-if any exists-is not important. However, red bentonites are significantly enriched in $\mathrm{Fe}, \mathrm{Ca}, \mathrm{Na}$, $\mathrm{K}$, and $\mathrm{P}$, compared to white/gray bentonites (see Table 2 ).

The results of our XRF analyses are summarized in Table 2 .

Several diagrams for discriminating volcanic rocks have been developed in the last few years. Because our bentonites are of trachyandesitic to dacitic composition, according to the commonly used diagrams: $\left(\mathrm{Na}_{2} \mathrm{O}+\mathrm{K}_{2} \mathrm{O}\right) / \mathrm{SiO}_{2}$ (Fig. 6) and $\mathrm{K}_{2} \mathrm{O} / \mathrm{SiO}_{2}$, we can plot our XRF results in either diagrams used for basaltic rocks or in those used for granitic rocks. For discriminating basaltic rocks, the $\left(\mathrm{Zr} / \mathrm{TiO}_{2}\right) /(\mathrm{Nb} / \mathrm{Y})$ diagram (after Winchester and Floyd. 1977) is commonly used. Again, our analyses mostly fit in the trachyandesitic rocks (Fig. 7). When one plots our data in a diagram that differentiates among geodynamic settings for magma generation (Fig. 8), one can see that our bentonites cannot be simply ascribed to a single and geochemically simple source. According to the TiZr-diagram (Fig. 8; Pearce et al., 1981), our bentonites are similar to island-arc basalts as well as within-plate basalts. According to the $\mathrm{Cr} / \mathrm{Y}$-diagram (Pearce, 1982), our bentonites might belong to both volcanic-arc and mid-ocean ridge (MORB) basalts (both differentiated). When one plots our chemi$\mathrm{cal}$ data in the most important diagram for granitic rocks: $\mathrm{Nb} / \mathrm{Y}$ diagram (Fig. 9), after Pearce et al. (1984), again, it is obvious that our bentonites fit partly the within-plate granites and partly the volcanic-arc granite field. Although one must treat them with care because of diagenesis and mixing with detrital material, at least two different volcanic sources for the ashes may have existed. When one plots the $\mathrm{SiO}_{2}$-content of Site 765 bentonites vs. time, a clear evolution of the ashes toward $\mathrm{SiO}_{2}$-rich rocks exists (Fig. 10), a result that is in agreement with differentiation with time observed commonly in a single magma chamber, but might also reflect magmatic evolution of a volcanic field over a considerable time period.

We tried to find trends in trace metal contents; however, no significant trend was observed, either with time or within the different sites. Nevertheless, one interesting relationship was observed: $\mathrm{Ba}$ and $\mathrm{P}_{2} \mathrm{O}_{5}$ show a strong positive correlation (barite and apatite in the heavy mineral fraction; Fig. 11). These results may have two reasons. Either the barite is of volcanic origin-which is unlikely - or the apatite is authigenic-which would be supported by the comparably high values of $\mathrm{Ce}$ and $\mathrm{La}$ (Pl. 2, Fig. 5).

\section{Diagenetic Alteration of Ash Layers}

Clearly, our bentonites represent the diagenetically homogenized end products of what were originally vitric ash layers of trachyandestic to dacitic composition. The alteration of silicic glass is a four-step process that involves (1) diffusion-controlled hydration and alkali exchange, (2) partial to complete dissolution of glass shards, (3) precipitation of montmorillonite, and (4) late-stage precipitation of clinoptilolite and other secondary phases in the remaining pore space. SEM (Pls. 2-4) and thin-section microscopy demonstrate the gradual alteration of silicic glass as follows:

1. Fresh or almost fresh glass shards are rare; because the refractive index is slightly lowered $(n=1.490)$, we cannot exclude a slight initial alteration (hydratization, ion exchange).

2. Slightly altered glass shards exhibit an etched surface with small corrosion pits with incipient smectite (or clinoptilolite) authigenesis.

3. Moderately altered (smectitized) glass shards with flat, V-shaped, coniform, or bubble-wall (vesicular) shard shapes still

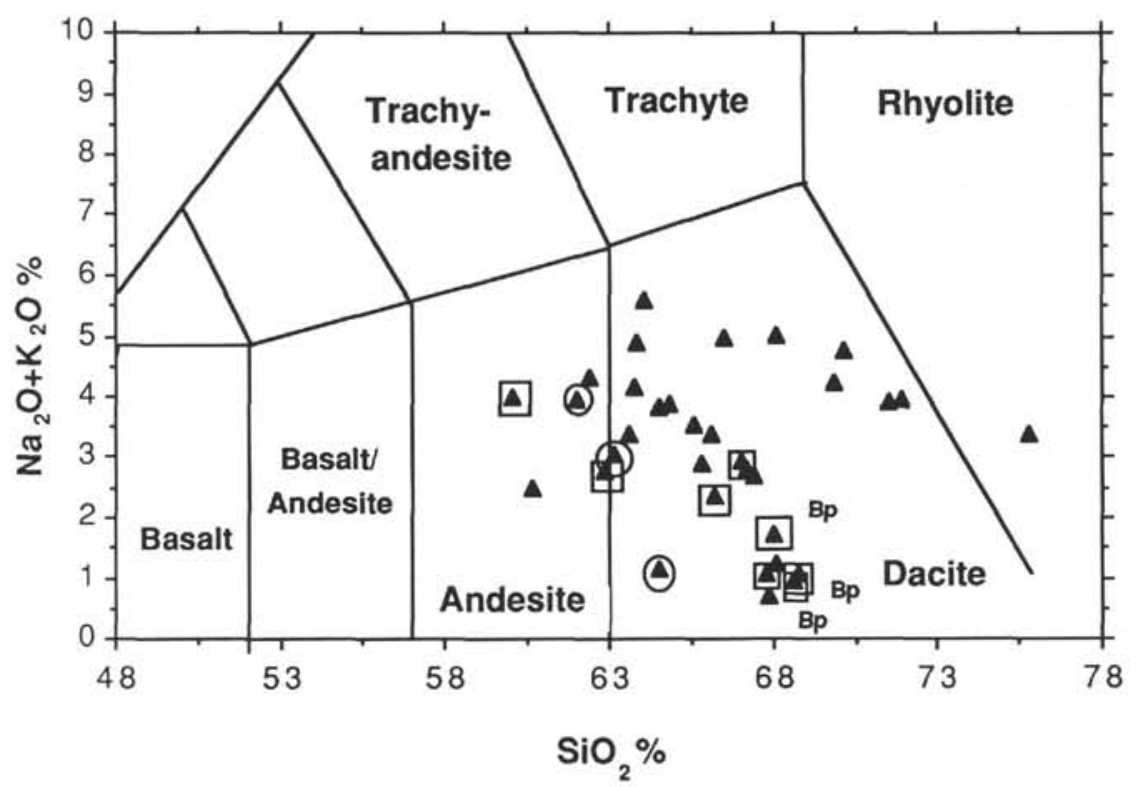

Figure 6. Total alkali $\left(\mathrm{Na}_{2} \mathrm{O}+\mathrm{K}_{2} \mathrm{O}\right)$ vs. $\mathrm{SiO}_{2}$; (TAS) diagram and rock classification of investigated ash layers after IUGS; LeBas et al., 1986). 


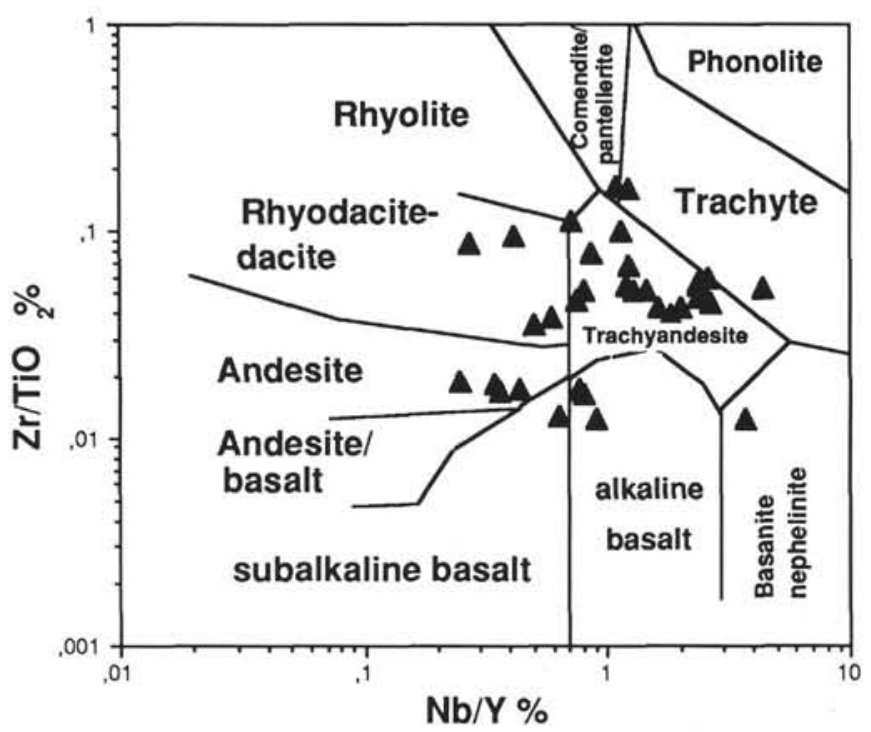

Figure 7. $\mathrm{Zr} / \mathrm{TiO}_{2}$ vs. $\mathrm{Nb} / \mathrm{Y}$ diagram and rock classification of investigated ash layers (Winchester and Floyd, 1977).

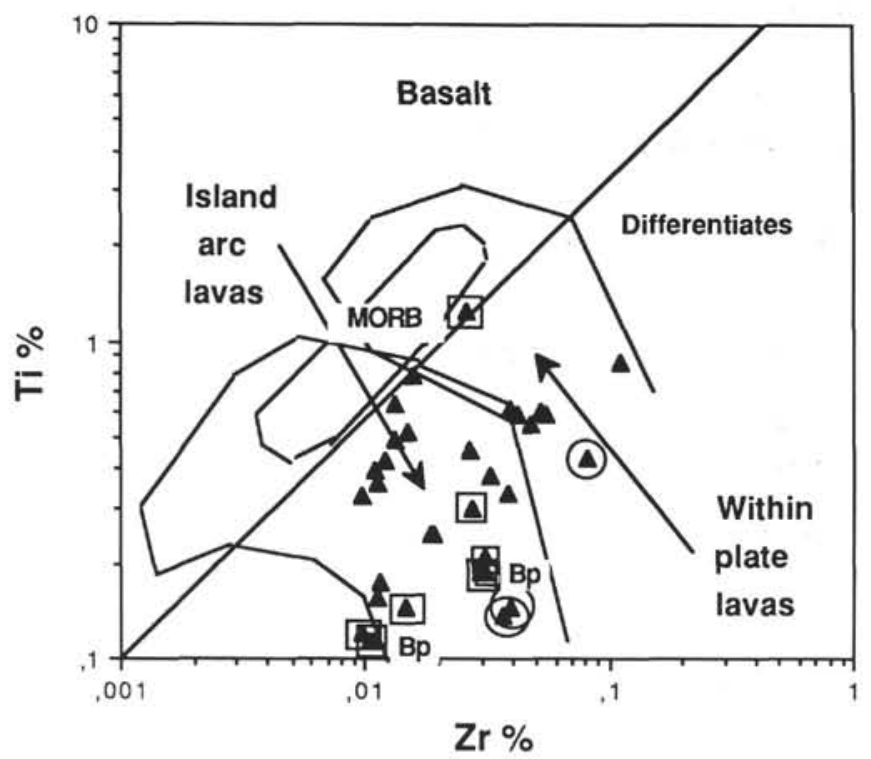

Figure 8. Proposed geodynamic setting of investigated ash layers in a $\mathrm{Ti}$ vs. $\mathrm{Zr}$ diagram (after Pearce et al., 1981).

intact (the glass matrix is, however, partly or completely dissolved), and montmorillonite-with the typical honeycomb structure-was reprecipitated in its place; we also observed partly or completely zeolitized glass shards, especially in bentonite B3 at Site 761 .

4. Completely smectitized bentonites, in which no vestiges of the original shape of glass shards could be observed. These bentonites commonly show that even plagioclase, K-feldspars, and other crystals are either overgrown by a dense network of montmorillonite or are totally replaced by smectite.

\section{DISCUSSION}

\section{Plate-Tectonic and Paleogeographic Settings (Latest Jurassic to Neocomian)}

The northwestern Australian passive continental margin is part of the eastern Gondwana continent facing the southern Tethys Sea

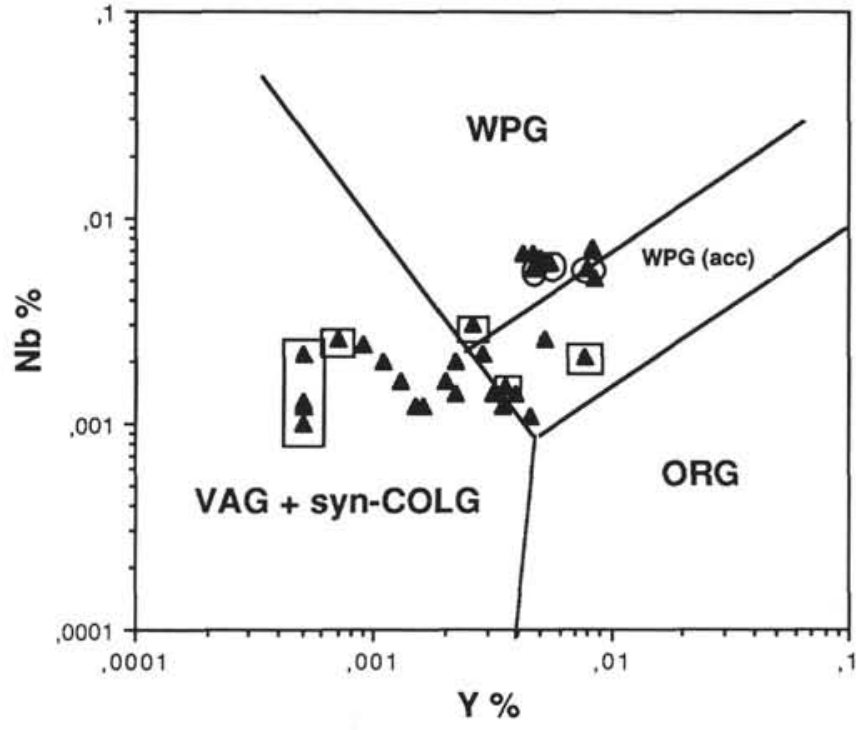

Figure $9 . \mathrm{Nb}$ vs. $\mathrm{Y}$ diagram for granitic rocks and rock classification of investigated ash layers (after Pearce et al., 1984). VAG + syn-COLG: volcanic-arc granites + syn-collisional granites; within-plate granites; (acc): within-plate granites in areas with thinned continental crust; ORG: oceanic ridge granites.

(von Rad and Thurow, 1992; Gradstein et al., 1989). During middle to Late Jurassic time, large parts of the Wombat and Exmouth plateaus were uplifted above sea level and represented an area of erosion or nondeposition. During Late Jurassic time, continental breakup between Gondwana (northern Exmouth Plateau) and its hypothetical conjugate margin, the "Argo Landmass," was followed by seafloor spreading and rapid subsidence of the Argo Abyssal Plain (Fig. 2). This "birth" of the oldest part of the Indian Ocean was followed by the deposition of a peculiar suite of hemipelagic "juvenile ocean sediments" of Neocomian age. On the Wombat Plateau, these "juvenile ocean" sediments consist of a transgressive series of condensed, littoral-to-nearshore sands and shelfal, belemnite-bearing, sandy silts, followed by hemipelagic calcisphere nannofossil chalks that alternate with thick bentonite layers. On the Argo Abyssal Plain, pelagic, reddish-to-greenish (radiolarian) claystones having thin bentonite intercalations were deposited at a water depth of about $3 \mathrm{~km}$. The final separation of greater India and Australia, which created the Gascoyne and Cuvier abyssal plains, started during late Valanginian (M10) time (Veevers, Heirtzler, et al., 1974; Fullerton et al., 1989). This breakup event has been constrained by magnetic anomalies, the oldest sediments overlying oceanic crust at Site 766 (late Valanginian; Ludden, Gradstein, et al., 1990), and by the breakup unconformity in Sites 762 and 763, separating the pre-breakup clastic wedge of the "Barrow Group" (Berriasian to Valanginian), and a transgressive Hauterivian-to-Aptian organicrich claystone series (Boyd and Bent, in press).

All the investigated bentonite layers are of late Berriasian to Valanginian age. However, they were recovered from five distinctly different sedimentary and plate-tectonic settings (Figs. 2 and 12), described as follows:

1. Distal prodelta claystones of the "Barrow Group" clastic margin wedge (Site 763, water depth about 100-200 m, comparatively high sedimentation rate).

2. Glauconitic and volcaniclastic sandstones and siltstones (latest Valanginian) interbedded with inclined basaltic sills in the easternmost Gascoyne Abyssal Plain, at the western foot of the Exmouth Plateau (Site 766, paleowater depth of 800-1000 m, high sedimentation rates, no connection to Barrow delta). 


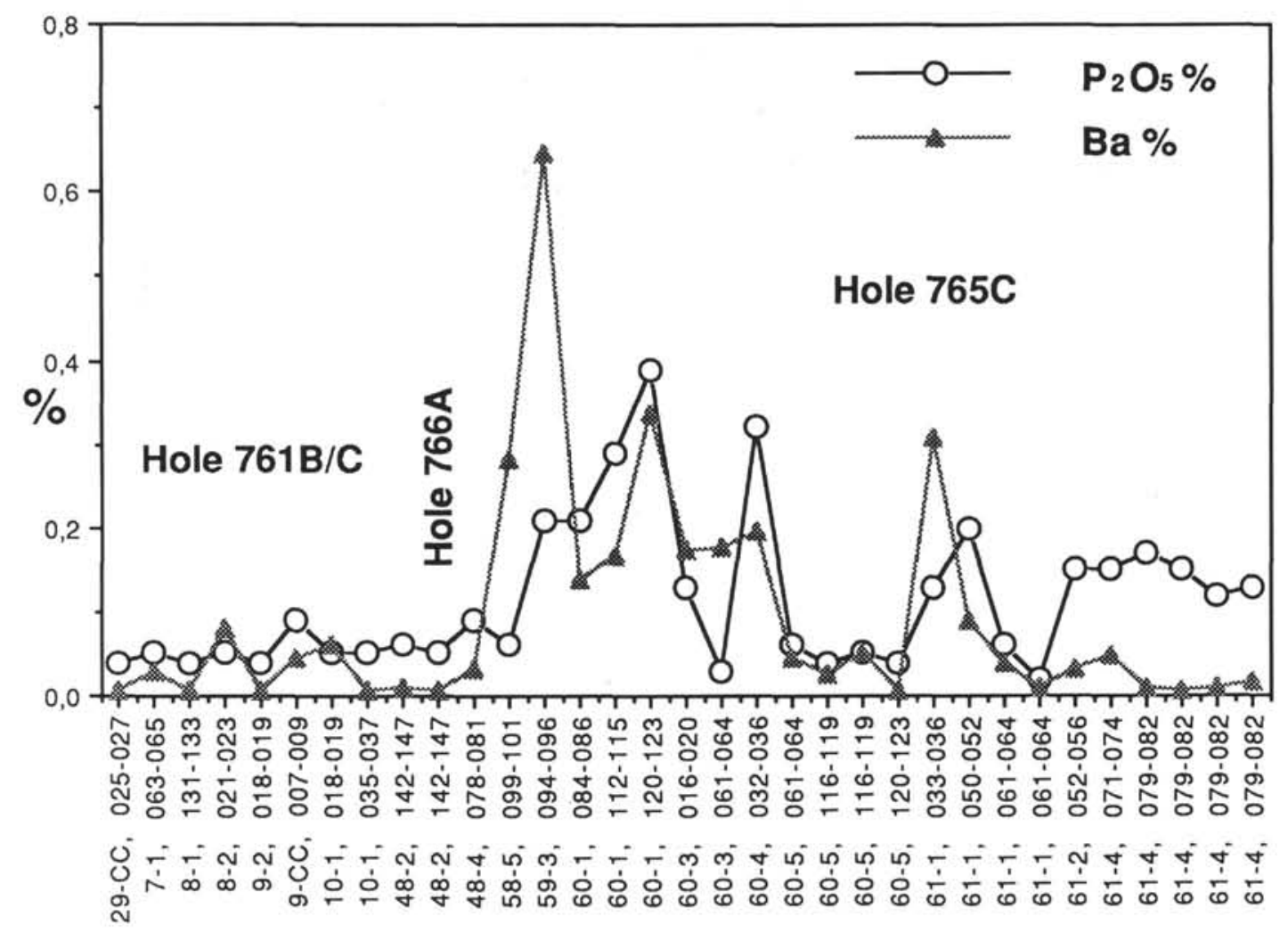

Figure 10. Correlation between $\mathrm{P}_{2} \mathrm{O}_{2}$ (interpreted as apatite) and $\mathrm{Ba}$ (interpreted as barite). Note the strong positive correlation in ashes from Hole $765 \mathrm{C}$.

3. Condensed, hemipelagic calcisphere-nannofossil chalks and marls, deposited on the rapidly subsiding, tilted block of the Wombat Plateau, part of which was probably still an emergent island (Site 761, paleowater depth rapidly increasing from $<100$ to several hundred meters, sedimentation only $3 \mathrm{~m} / \mathrm{m} . \mathrm{y}$.).

4. Pelagic, reddish-brown and greenish claystones and radiolarian silty claystones with carbonate turbidites in the southernmost Argo Abyssal Plain (Site 765, paleowater depth $>3500 \mathrm{~m}$ [?], sub-CCD, very low sedimentation rates).

5. Pelagic reddish-brown claystones in the central Argo Abyssal Plain (Site 261, paleowater depth $>3000 \mathrm{~m}$ [?], sub-CCD, very low sedimentation rates).

In addition to these different environments, bentonitic clays have been recorded from the Muderong Shale (Valanginian to Aptian) in the Carnarvon Basin, south of Exmouth Plateau (Hocking et al., 1987). These silty shales were deposited in a low-energy, restricted-marine environment during Valanginian to Aptian time, somewhat similar to the Hauterivian-to-Aptian sediments deposited on top of the Barrow Group equivalent series at Sites 762 and 763 .

\section{Post-Breakup Volcanism off Northwestern Australia}

Normal faulting in the extensional regime of the northwestern Australian passive margin started during late Permian to Triassic time with a climax during the Early to Middle Jurassic. Reactivation of these northeast to southwest-trending faults continued during Jurassic to early Neocomian time, when east to west-trending faults were created and seafloor spreading started at the Argo Abyssal Plain. During this time, greater India was elevated south of the Cape Range Fracture Zone, causing the northward progra- dation of major fluviodeltaic lobes of the Barrow Group toward central Exmouth Plateau (Fig. 2).

On Exmouth Plateau (Site 763), Wombat Plateau (Site 761), and in the adjacent Argo (Sites 261, 765) and Gascoyne abyssal plains (Site 766), we discovered altered ash layers that shed some light on the important volcanic events associated with the earliest stages of the opening of the Indian Ocean during early Neocomian time.

One would expect considerably enhanced igneous activity if the asthenosphere under Exmouth Plateau was comparatively hot and if the overlying lithosphere stretched and thinned during rifting and after the onset of oceanic spreading (White, 1989). Apparently, volcanic activity was not only associated with late Triassic to Liassic rift-block-faulting events of northern Exmouth Plateau (von Rad and Exon, 1983; von Rad et al., 1989), but also with the continental breakup and the following rapid subsidence at the continent/ocean boundary during Latest Jurassic to Neocomian time. This was a surprising discovery, because no direct evidence of Mesozoic volcanic activity was reported from the onshore or offshore parts of the Canning Basin (Towner and Gibson, 1983) or the Carnarvon Basin (Hocking et al., 1987). For northwestern Europe, a similar syn-breakup volcanic activity was reported for the Early Cretaceous ("Wealden"; Zimmerle, 1989). The same volcanic event was observed in the Tethys Himalaya (Thakkhola, central Nepal; Gradstein et al., 1989); this area represented a northward-facing continental margin of greater India, which prior to continental breakup was adjacent to the Exmouth Plateau.

Should we look for potential volcanic source areas for our bentonites off northwestern Australia during Early Cretaceous time, we must consider the following areas (shown in Figs. 2 and 12): 


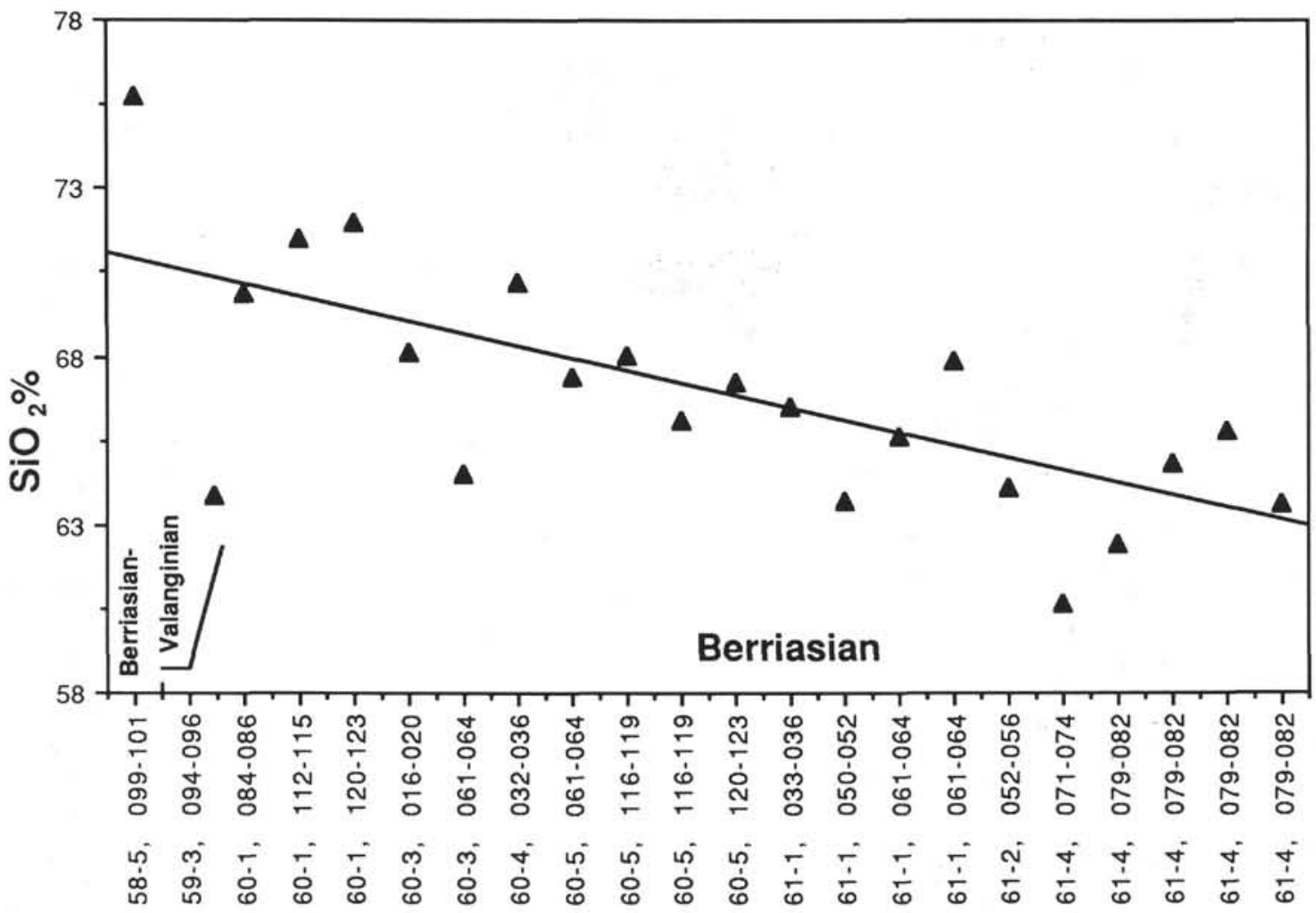

Figure 11. Plot of $\mathrm{SiO}_{2}$ vs. age for Hole $765 \mathrm{C}$ ashes. Note the constant increase with time of $\mathrm{SiO}_{2}$ interpreted as reflection of increasing differentiation of the original volcanic rocks.

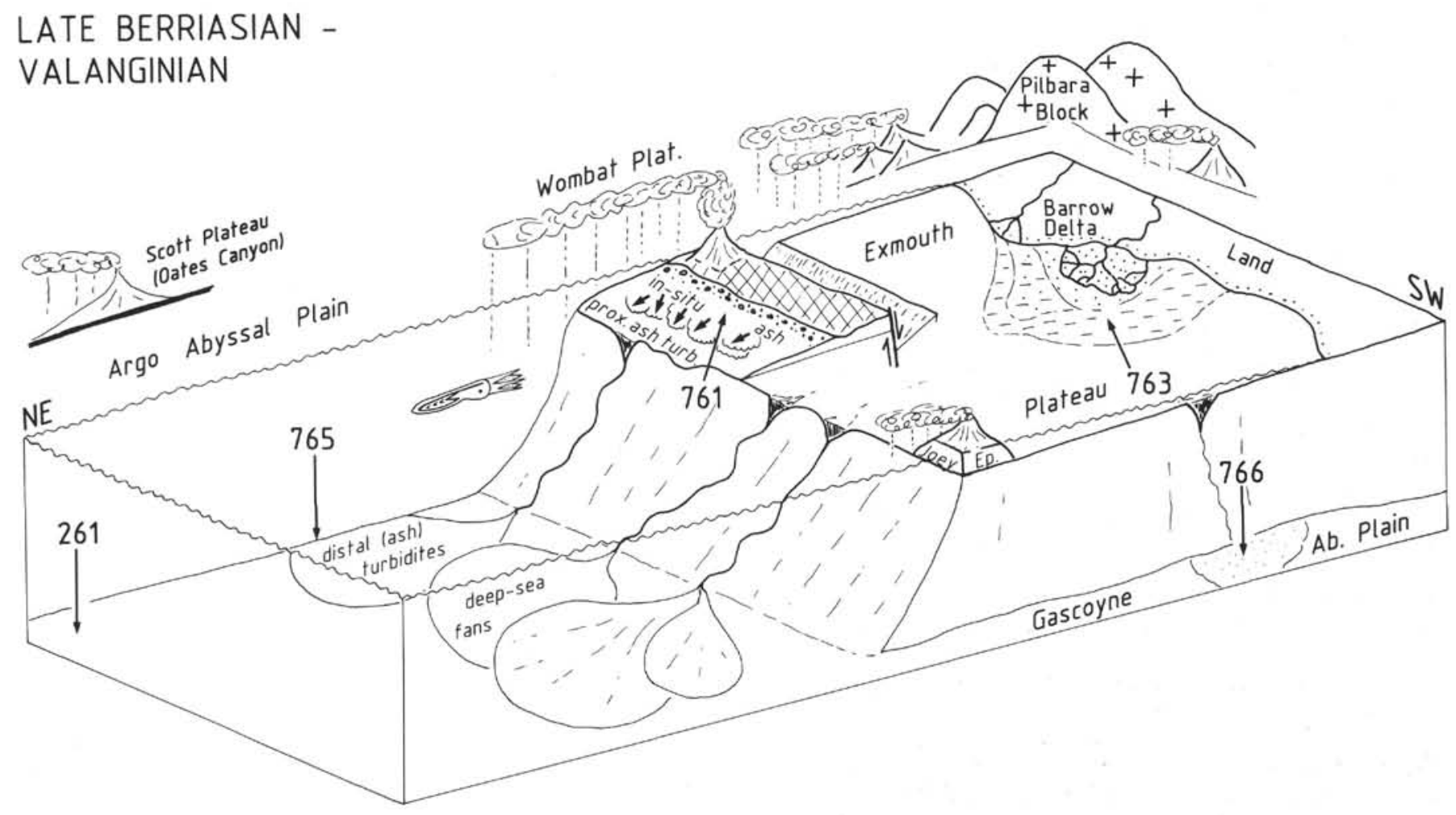

Figure 12. Schematic paleogeographic sketch of the northwestern Australian margin during early Neocomian time (see Fig. 2). Not to scale. Potential volcanic source areas for bentonites are speculative. 
1. Wombat Plateau: only indirect and speculative evidence exists for volcanic activity on the emergent part of Wombat Plateau or its vicinity during early Neocomian time. The bentonite layers here are thick (up to $0.7 \mathrm{~m}$ ) and have a cumulative thickness of at least $2.2 \mathrm{~m}$. Therefore, we assume a nearby chain of subaerial explosive volcanoes.

2. Joey and Roo rises (northwest of Joey Rise) are two large, separate, but adjacent, deeply submerged plateaus (together about $30,000 \mathrm{~km}^{2}$ ) at the northwestern projection of Exmouth Plateau that have a water depth of between 2500 and $4000 \mathrm{~m}$ and are probably not underlain by continental, but oceanic or "mixed," crust (Figs. 2, 1B). Veevers and Cotterill (1978) suggested that these plateaus were formed by abnormally thick volcanic upgrowth ("epilith") during or after the breakup of Argo Abyssal Plain. This interpretation is supported by hyaloclastites and basalts cored at the northeastern slopes of both rises (Cook et al., 1978). Although these volcanic rocks could not be dated, the outcrops below or near the seismically detected "breakup unconformity" suggest that submarine basaltic volcanism was active during Latest Jurassic to Neocomian time. Possibly, the volcanic growth of the Joey/Roo epilith coincides with the injection of the dikes into the upper Valanginian sediments of Site 766. We cannot exclude the possibility that during this time part of the Joey Rise was above sea level and supplied wind-borne ash material to the Argo Abyssal Plain and Wombat Plateau.

3. Scott Plateau/Oates Canyon: Middle to Late Jurassic volcanism is well known from the vicinity of Scott Plateau (Scott Reef No. 1 well), located northeast of Exmouth Plateau and east of Argo Abyssal Plain (Fig. 2). The Valdivia dredged a great variety of volcanic and volcaniclastic rocks from Oates Canyon at the western plateau margin (Hinz et al., 1978). The least-weathered of these volcanic rocks are differentiated alkali basalts having a K/Ar age of 128 to $132 \mathrm{Ma}$, i.e., early Neocomian (von Rad and Exon, 1983). This age fits well with the Berriasian age of the oldest sediments overlying oceanic basalt at Site 765 and suggests that the Scott Plateau volcanism is co-eval with the earliest stages of the opening of the Argo Abyssal Plain.

4. Wallaby Plateau: a large submarine plateau, south of Exmouth Plateau, that Veevers and Cotterill (1978) also interpreted as a huge volcanic "epilith" $\left(30,000 \mathrm{~km}^{2}\right.$ area $\times$ about $1 \mathrm{~km}$ thick $=$ about $30,000 \mathrm{~km}^{3}$ volume). A brief, but spectacular, volcanic event apparently followed the late Neocomian breakup between Australia and "Greater India" and the start of seafloor spreading in the Gascoyne, Cuvier, and Perth abyssal plains. Wallaby Plateau experienced an origin similar to Iceland, but with an abrupt cessation of volcanism and subsidence below sea level after the spreading ridge of Cuvier Abyssal Plain jumped to its new position farther northwest (von Rad and Exon, 1983). The age of the tholeiitic basalts dredged from Wallaby Plateau and those sampled on the associated Sonne Ridge (Cuvier Abyssal Plain) is not well constrained (K/Ar age "older than Turonian"). Based on magnetic anomalies, we assume an age of Hauterivian to Aptian.

Seismic reflection profiles across the southernmost Exmouth Plateau near the Cape Range Fracture Zone suggest volcanic intrusions that are probably associated with the westward motion of "Greater India" along the Exmouth Plateau's southern transform margin during about late Valanginian time (R. Boyd, pers. comm., 1991).

If one assumes that the ashes were distributed northwestward by high-altitude eastern trade winds (similar to the present-day wind circulation), one can speculate that the ash layers of the Argo Abyssal Plain were derived from volcanoes near Scott Plateau and/or Wombat/Northern Exmouth plateaus and that the Wombat Plateau ashes come from a nearby source ([?]Wombat Plateau). The southern Exmouth Plateau and Gascoyne Abyssal Plain ash layers were probably derived from volcanoes located to the south and southeast of these areas (Fig. 12). The explosive volcanism had a highly differentiated (dacitic to rhyolitic) composition.

\section{Dispersal and Mode of Deposition of Ash Layers}

Ash layers mark short-lived geological events and thus represent ideal stratigraphic marker horizons, if they can be correlated among closely spaced sites (cf. von Rad and Mühe, 1990). Unfortunately, the Wombat Plateau and Argo Abyssal Plain sites are too far apart and have paleobathymetric and paleotectonic settings too different to be directly correlated (Fig. 1B). The same holds true for the southern Exmouth Plateau Site 763 and the eastern Gascoyne Abyssal Plain Site 766. Therefore, we have to restrict this discussion to a consideration of the estimated volume and deposition/redeposition mechanisms of the ashes within the four areas represented by Sites 765, 761, 763, and 766 (Fig. 12).

Widespread submarine ash layers usually are derived from explosive subaerial volcanoes or chains of volcanoes, that distribute vitreous ash of dacitic to rhyolitic composition via high-altitude winds (Fisher and Schmincke, 1984). In marginal basins behind island-arc volcanoes, such as the Lau Basin, filled with Quaternary sediments, we observed (1) finely dispersed ash (up to $10 \%$ silt-sized volcanic glass, mixed with hemipelagic sediments), (2) distinct air-fall ash layers up to $15 \mathrm{~cm}$ thick that consist mostly of glass with a downwind decrease of the crystal/glass ratio, usually without laminations or grading, and (3) thick, laminated and graded, poorly sorted ash turbidites having distinct lower and indistinct upper boundaries (von Rad and Mühe, 1990).

Because of the strong alteration of the glass to clay minerals (smectite), it is unlikely that finely dispersed ash might be discovered in our Neocomian sediments. The following criteria indicate that the Wombat Plateau bentonites were rapidly deposited as proximal ash turbidites:

1. Their great thickness $(10-70 \mathrm{~cm})$ that encompasses about $10 \%$ of the total Neocomian sediment thickness at Site 761.

2. The distinct lower contacts to the underlying calcisphere nannofossil chalks.

3. The (generally) diffuse upper boundaries of the bentonites, disturbed by bioturbation down the core from above (upward transition into the hemipelagic chalk).

4. The faint lamination to even indistinct cross-lamination in some bentonites (especially B6).

If one postulates that most of the Wombat Plateau bentonites (B1 to B6) are ash turbidites, one must assume that in-situ air-fall ash layers were deposited originally on the shelf and then redeposited by turbidity currents or mass-flow downslope into marginal basin, outer-shelf, or upper-slope environments.

According to a rough estimate, the ash layers of the Wombat Plateau have a cumulative thickness of about $3 \mathrm{~m}$ and a volume on the order of a few cubic kilometers (assuming an area of about $1000 \mathrm{~km}^{2}$ for the submerged part of Wombat Plateau). This compares well with the volume of correlated ash turbidites in the Lau Basin (up to $>0.8 \mathrm{~km}^{3}$ ) and to the volume of ash erupted by Mount St. Helens $\left(1.3 \mathrm{~km}^{3}\right)$.

The bentonites of Site 765 in the Argo Abyssal Plain are much thinner than those from the Wombat Plateau and, hence, have been interpreted as distal ash turbidites that were periodically redistributed downslope from the Wombat and northeastern Exmouth Plateau shelf by turbidity currents and, finally, deposited on large, distal deep-sea fans that formed at the margins of the rapidly subsiding abyssal plain (Fig. 2). The volume of these ash turbidites is difficult to estimate, even if one assumes that the bentonites of Site 261 are the most distal representatives of ash layers found in Site 765 . If one assumes an area of $160,000 \mathrm{~km}^{2}$ for the 
Argo Abyssal Plain and a cumulative ash thickness of $10 \mathrm{~m}$, one arrives at an enormously high volume of $1600 \mathrm{~km}^{3}$ for all ash layers in this area. One can also speculate how far from the source area our bentonites were deposited. From the maximum particle size of the glass shards and crystals and the $\mathrm{SiO}_{2}$ content of wind-transported ash ("eolian fractionation"), one can estimate the transport distances of air-fall ashes. The thick Wombat Plateau bentonites contain coarse particles (glass shards, feldspar crystals, rock fragments) having a size of about $100 \mu \mathrm{m}(30-150 \mu \mathrm{m})$, suggesting a transport distance of not more than a few tens to 200 km (Winkler et al., 1985; von Rad and Mühe, 1990).

The Argo Abyssal Plain bentonites are not only thinner, but also contain fewer and smaller crystals; because of "eolian fractionation," they have higher $\mathrm{SiO}_{2}$ contents (up to $71 \% \mathrm{SiO}_{2}$ in LOI-free samples), probably caused by the relative downwind concentration of lightweight silicic glass vs. heavier (less silicic) glass, crystals, and lithic components (Fisher and Schmincke, 1984). Therefore, we assume transport distances of a few hundred to $>500 \mathrm{~km}$ for the Argo Abyssal Plain bentonites of Sites 765 and 261 .

\section{CONCLUSIONS}

1. Bentonites, i.e., "argillized" volcanic ash layers of trachyandestic to dacitic composition altered to smectite-dominated claystones, were discovered in Berriasian to Valanginian sediments of the Wombat Plateau (Site 761, hemipelagic "juvenile ocean" setting), of the Argo Abyssal Plain (Site 261, 765, pelagic claystones, etc.), of the southern Exmouth Plateau (Site 763, shelfal prodelta mudstone), and of the easternmost Gascoyne Abyssal Plain (Site 766, hemipelagic sandy mudstone; Fig. 2).

2. A volcaniclastic origin of these bentonitic claystones is proved by (1) the abundance of well-ordered dioctahedral montmorillonite; (2) the presence of fresh to altered silicic glass shards of K-rich dacitic composition; (3) the presence of euhedral sanidine, clinopyroxene, and volcanic rock fragments; (4) a typical apatite and (slender) zircon-dominated heavy mineral association; and (5) a vitroclastic ultrafabric that consists of smectitized glass shards having the typical "honeycomb texture" of montmorillonite.

3. Mineralogically and chemically, we distinguished (1) white, pink, light-gray, pure smectite bentonites having a waxy appearance, and a homogeneous cryptocrystalline smectite matrix and (2) dark gray, gray, and brown impure bentonites, mixtures of volcanogenic smectite and pyroclastic grains having nonvolcanic (terrigenous and pelagic) components and a variable chemical composition.

4. Diagenetic alteration includes smectite and zeolite authigenesis. Alteration of silicic glass shards proceeds from (1) fresh (possibly hydrated) glass to (2) slightly altered (etched) glass with corrosion pits having incipient smectite authigenesis to (3) moderately altered (smectitized) glass (with the shard shape generally intact) to (4) completely homogenized pure smectite bentonites without obvious vestiges of the original ashy material. Euhedral clinoptilolite, generally post-dating smectite genesis, is the main zeolite mineral and has been precipitated in the open pore space (or replaced glass shards). However, most of this mineral might have been derived from the dissolution of opaline skeletons, rather than from volcanic glass as parent material.

5. Volcanic activity was associated with continental breakup and the following rapid subsidence. Potential source areas that were volcanically active during Latest Jurassic to Neocomian (to Aptian) time include (Figs. 2, 12) (1) Wombat Plateau(?), (2) Joey and Roo rises (northwestern extension of Exmouth Plateau), (3) Scott Plateau (Oates Canyon) east of Argo Abyssal Plain, and (4) Wallaby Plateau/Cape Range Fracture Zone south of Exmouth Plateau.
6. We speculate that westward-directed high-altitude trade winds transported silicic ash from these volcanic source areas to the Exmouth Plateau and the adjacent abyssal plains. The Wombat Plateau bentonites are explained as proximal ash turbidites because of their great thickness, color and size(?) grading, distinct lower and gradational upper contacts, and parallel and cross-lamination. The total ash volume of the six to seven bentonite layers is a few cubic kilometers, and the distance of the source area, a few ten to $200 \mathrm{~km}$. The Argo Abyssal Plain bentonites are much thinner and finer-grained(?); they are explained as distal ash turbidites that were deposited on deep-sea fans, which derived from the northern Exmouth Plateau.

\section{ACKNOWLEDGMENTS}

The Deutsche Forschungsgemeinschaft (Bonn) supported this research by ODP grants ( $\mathrm{Ra} 191 / 10$, Wi 112/27). We thank the following colleagues for helping us with their expertise: Bitschine (Bochum, F.R.G.) for his help regarding composition and interpretation of volcaniclastics and W. Zimmerle for his advice about how to tackle the investigation of bentonites. Zinkernagel (Bochum) supplied the excellent thin sections; Hüttemann (Tübingen) helped with his expertise in SEM/EDX analysis. We thank the Ocean Drilling Program for its invitation to participate during Legs 122 (U. von Rad) and 123 (J. Thurow) on board the JOIDES Resolution.

We thank Brian L. Cousens (Montreal) for improving the manuscript, review, and criticism, and anonymous reviewers for their valuable suggestions.

\section{REFERENCES}

Barber, P. M., 1982. Paleotectonic evolution and hydrocarbon genesis of the central Exmouth Plateau. APEA J., 22:131-144.

1988. The Exmouth Plateau deep water frontier: a case history. In Purcell, P. G., and Purcell, R. R. (Eds.), The North West Shelf. Australia: Proc. Pet. Expl. Soc. Aust. Symp., 173-187.

Bitschene, P. R., Schmincke, H.-U., and Viereck, L., 1989. Cenozoic ash layers on the Vøring ringringPlateau (ODP Leg 104). In Eldholm, O., Thiede, J., Taylor, E., et al., Proc. ODP, Sci. Results, 104: College Station, TX (Ocean Drilling Program), 357-366.

Boote, D.R.D., and Kirk, R. B., 1989. Depositional wedge cycles on an evolving plate margin, western and northwestern Australia. AAPG Bull., 73:216-243.

Bradshaw, M. T., Yeates, A. N., Beynon, R. M., Brakel, A. T., Langford, R. P., Totterdell, J. M., and Yeung, M., 1988. Paleogeographic evolution of the North West Region. In Purcell, P. G., and Purcell, R. R. (Eds.) The North West Shelf. Australia: Proc. Pet. Expl. Soc. Aust. Symp., 29-54.

Carey, S. H., and Sigurdson, H., 1984. A model of volcanogenic sedimentation in marginal basins. In Kokelaar, B. P., and Howells, M. F. (Eds.), Margin Basin Geology. Geol. Soc. London, 37-58.

Cook, P. J., Veevers, J. J., Heirtzler, J. R., and Cameron, P. J., 1978. The sediments of the Argo Abyssal Plain and adjacent areas, northeast Indian Ocean. BMR J. Aust. Geol. Geophys., 3:113-124.

Fisher, R. V., and Schmincke, H.-U., 1984. Pyroclastic Rocks: New York (Springer-Verlag).

Fullerton, L. G., Sager, W. W., and Handschumacher, D. W., 1989. Late Jurassic-Early Cretaceous evolution of the eastern Indian Ocean adjacent to Northwest Australia. J. Geophys. Res., 94:2937-2953.

Gradstein, F. M., Gibling, M. R., Jansa, L. F., Kaminski, M. A., Ogg, J. G., Sarti, M., Thurow, J. W., von Rad, U., and Westermann, G.E.G., 1989. Mesozoic Stratigraphy of Thakkhola, Central Nepal. Spec. Rep. Cent. Mar. Geol. Dalhousie Univ., 1:1-115.

Grim, R. E., and Güven, N., 1978. Bentonites: Geology, Mineralogy, Properties, and Uses: Amsterdam (Elsevier).

Haq, B. U., Hardenbol, J., and Vail, P. R., 1987. Chronology of fluctuating sea levels since the Triassic. Science, 235:1156-1167.

Haq, B. U., von Rad, U., O'Connell, S., et al., 1990. Proc. ODP, Init. Repts., 122: College Station, TX (Ocean Drilling Program). 
Heirtzler, J. R., Cameron, P., Cook, P. J., Powell, T., Roeser, H. A., Sukardi, S., and Veevers, J. J., 1978. The Argo Abyssal Plain. Earth Planet. Sci. Lett., 41:21-31.

Hinz, K., Beiersdorf, H., Exon, N. F., Roeser, H. A., Stagg, H.M.J., and von Stackelberg, U., 1978. Geoscientific investigations from the Scott Plateau off Northwest Australia to the Java Trench. BMR J. Aust. Geol. Geophys., 3:319-340.

Hocking, R. M., Moors, M. T., and van der Graaff, W.J.E., 1987. The geology of the Carnarvon Basin, Western Australia. Bull.-Geol. Surv. West. Aust., No. 133.

Huber, N. K., and Rinehart, D. D., 1966. Some relationships between the refractive index of fused glass beads and the petrologic affinity of volcanic rock suites. Geol. Soc. Am. Bull., 77:101-110.

Koňta, J., 1986. Textural variation and composition of bentonite derived from basaltic ash. Clays Clay Miner., 34:257-265.

Kopsen, E., and McGann, G., 1985. A review of the hydrocarbon habitat of the eastern and central Barrow-Dampier Sub-Basin, Western Australia. APEA J., 25:154-175.

Le Bas, M. J., Le Maitre, R. W., Streckeisen, A., and Zanettin, B., 1986. A chemical classification of volcanic rocks based on the total alkalisilica diagram. J. Petrol., 27:745-750.

Ludden, J. N., Gradstein, F. M., et al., 1990. Proc. ODP, Init. Repts., 123: College Station, TX (Ocean Drilling Program).

Pearce, J. A., 1982. Trace element characteristics of lavas from destructive plate boundaries. In Thorpe, R. S. (Ed.), Andesites: Orogenic Andesites and Related Rocks: New York (Wiley), 525-548.

Pearce, J. A., Alabaster, T., Shelton, A. W., and Searle, M. P., 1981. The Oman ophiolite as a Cretaceous arc-basin complex: evidence and implications. Philos. Trans. R. Soc. London, A300:299-317.

Pearce, J. A., Harris, N.B.W., and Tindle, A. G., 1984. Trace element discrimination diagrams for the tectonic interpretation of granitic rocks. J. Petrol., 25:956-983.

Powell, D. E., 1976. The geological evolution and hydrocarbon potential of the continental margin off northwest Australia. APEA J., 16:13-24.

Pupin, J. P., 1980. Zircon and granite petrology. Contrib. Mineral. Petrol., 73:207-220.

Schmincke, H. U., 1989. Pyroklastische Gesteine. In Füchtbauer et al. (Eds.), Sedimente und Sedimentgesteine: Stuttgart (Schweizerbart), 731-778.

Shipboard Scientific Party, 1974. Site 251. In Veevers, J. J., Heirtzler, J. R., et al., Init. Repts. DSDP, 27: Washington (U.S. Govt. Printing Office), $129-192$. 1990a. Site 761. In Haq, B. U., von Rad, U., et al., Proc. ODP. Init. Repts., 122: College Station, TX (Ocean Drilling Program), 161-211.

1990b. Site 765. In Ludden, J. N., Gradstein, F. M., et al., Proc. $O D P$, Init. Repts., 123: College Station, TX (Ocean Drilling Program), 63-267.

Towner, R. R., and Gibson, D. L., 1983. Geology of onshore Canning Basin, Western Australia. BMR Bull., No. 215.
Veevers, J. J., 1988. Morphotectonics of Australia's northwestern margin. In Purcell, P. G., and Purcell, R. R. (Eds.), The North West Shelf Australia. Proc. Pet. Expl. Soc. Aust. Symp., 173-187.

Veevers, J. J., and Cotterill, D., 1978. Western margin of Australia: evolution of rifted arch system. Geol. Soc. Am. Bull., 89:337-355.

Veevers, J. J., Heirtzler, J. R., et al., 1974. Init. Repts. DSDP. 27: Washington (U.S. Govt. Printing Office).

von Rad, U., and Exon, N. F., 1983. Mesozoic-Cenozoic sedimentary and volcanic evolution of the starved passive continental margin off northwest Australia. In Watkins, J. S., Drake, C. L., and Sheridan, R. E. (Eds.), Studies in Continental Margin Geology: AAPG Mem., $34: 253-281$

von Rad, U., Haq, B. U., et al., 1992. Proc. ODP, Sci. Results, 122: College Station, TX (Ocean Drilling Program).

von Rad, U., and Mühe, R., 1990. Mineralogy, chemical composition and origin of ash layers and pumice in sediments from the Lau and North Fiji Basins (SW Pacific, SO-35 Cruise). Geol. Jahrb., D92:279-339.

von Rad, U., and Thurow, J., 1992. Bentonitic clays as early Necomian post-breakup. In von Rad, U., Haq, B. U., et al., Proc. ODP, Sci. Results, 122: College Station, TX (Ocean Drilling Program), 213 232.

von Rad, U., Thurow, J., Haq, B. U., Gradstein, F., Ludden, J., and ODP Leg 122/123 Shipboard Scientific Parties, 1989. Triassic to Cenozoic evolution of the NW Australian continental margin and the birth of the Indian Ocean (preliminary results of ODP Legs 122 and 123). Geol. Rundsch., 78:1189-1210.

White, R., 1989. Volcanism and igneous underplating in sedimentary basins and at rifted continental margins. In Price, R. A. (Ed.), Origin and Evolution of Sedimentary Basins and Their Energy and Mineral Resources. Int. Union Geol. Geophys., Geophys. Monogr. 48, Vol. $3: 125-127$.

Winchester, J. A., and Floyd, P. A., 1977. Geochemical discrimination of different magma series and their differentiation products using immobile elements. Chem. Geol., 20:325-343.

Winkler, W., Galetti, G., and Maggetti, M., 1985. Bentonite im Gurnigel-, Schlieren- und Wägital-Flysch: Mineralogie, Chemismus, Herkunft. Eclogae Geol. Helv., 78:545-564.

Zimmerle, W., 1989. Vestiges of volcanic activity in Cretaceous sediments of Europe. In Wiedmann, J. (Ed.), Cretaceous of the Western Tethys. Proc. 3rd Inter. Cretaceous Symp., Tübingen 1987, 951-987.

Zimmerle, W., and Gaida, K.-H., 1980. Identification of ancient tuffs and volcanic components in progressively altered ancient argillaceous sediments. A discussion. Int. Assoc. Sedimentol., First Europ. Meet. Bochum 1980, 251-254. (Abstract)

Date of initial receipt: 19 June 1990

Date of acceptance: 6 May 1991

Ms 123B-150 


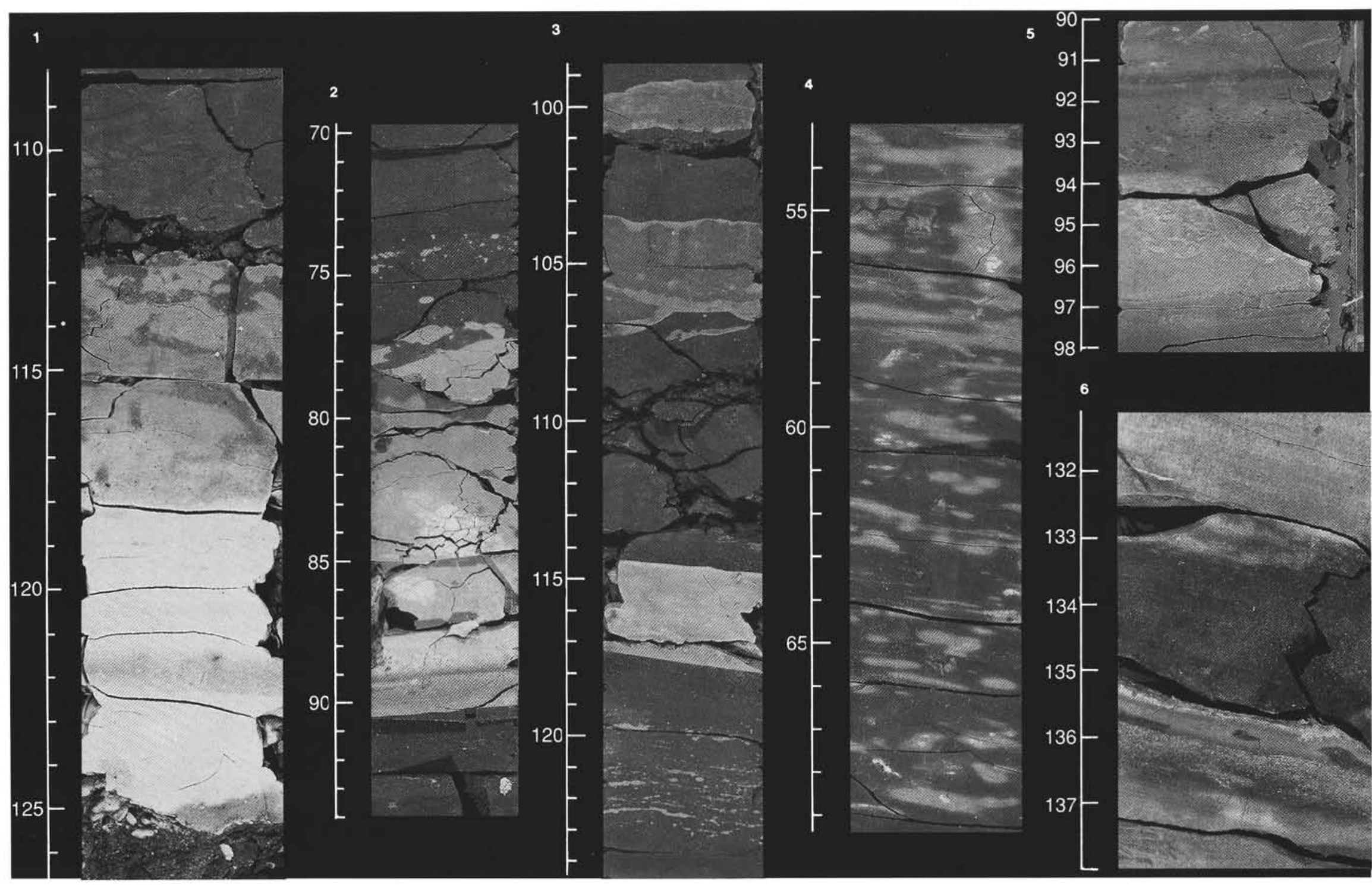

Plate 1. Types of bentonitic claystones in basal cores of Hole 765C. 1. Interval 123-765C-60R-5, 108-127 cm, Type 1. 2. Interval 123-765C-61R-4, 69-94 cm, Type 1. 3. Interval 123-765C-61R-1, 99-124 cm, Type 2. 4. Interval 123-765C-60R-4, 53-69 cm, Type 3. 5. Interval 123-765C-59R-3, 90-98 cm, Type 4. 6. Interval 123-765C-58R-2, 131-138 cm, Type 4. 


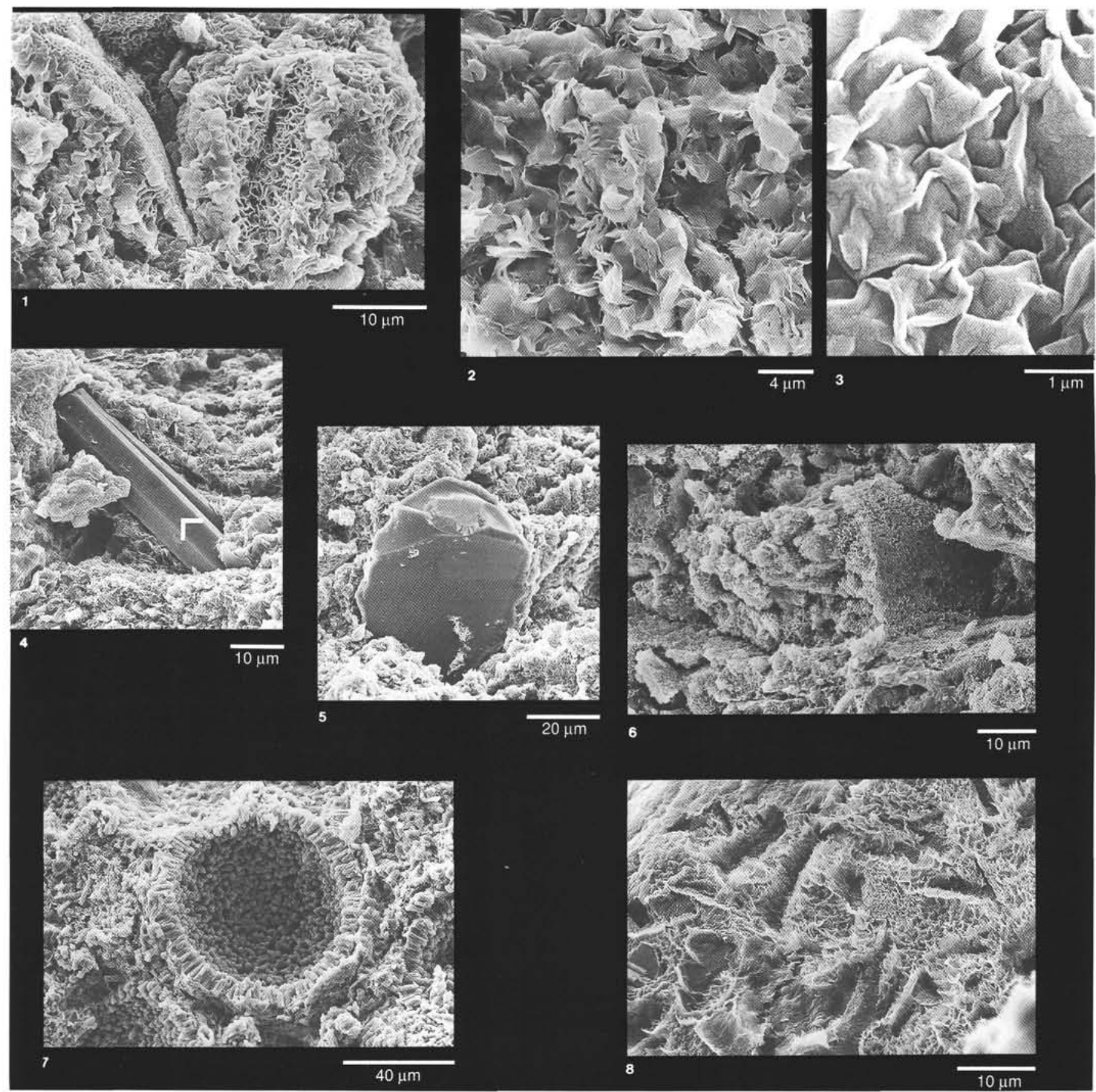

Plate 2. SEM pictures. 1. Sample 122-761 B-29R-CC, $25-27 \mathrm{~cm}$ : smectite showing "honeycomb texture" typical for smectite-replaced glass shards. 2. Sample 123-765C-60R-5, 120-123 cm: pure dioctaedric smectite. 3. Sample 123-765C-60R-5, 120-123 cm: pure dioctaedric smectite. 4. Sample 123-765C-61R-4, 79-82 cm: apatite crystal in smectite. 5. Sample 122-761B-29R-CC, 25-27 cm: apatite crystal with Ce/La-nucleous (visible on top). 6. Sample 123-765C-57R-7, 8-10 cm: "honeycomb" texture. 7. Sample 123-765C-61R-3, 19-20 cm: calcispheres in smectite-matrix. 8. Sample $123-766 \mathrm{~A}-48 \mathrm{R}-4,78-81 \mathrm{~cm}$ : smectite fabric in fine-grained, waxy volcaniclastic sandstone from Hole 766A. Open cavities mark original detrital grains. 


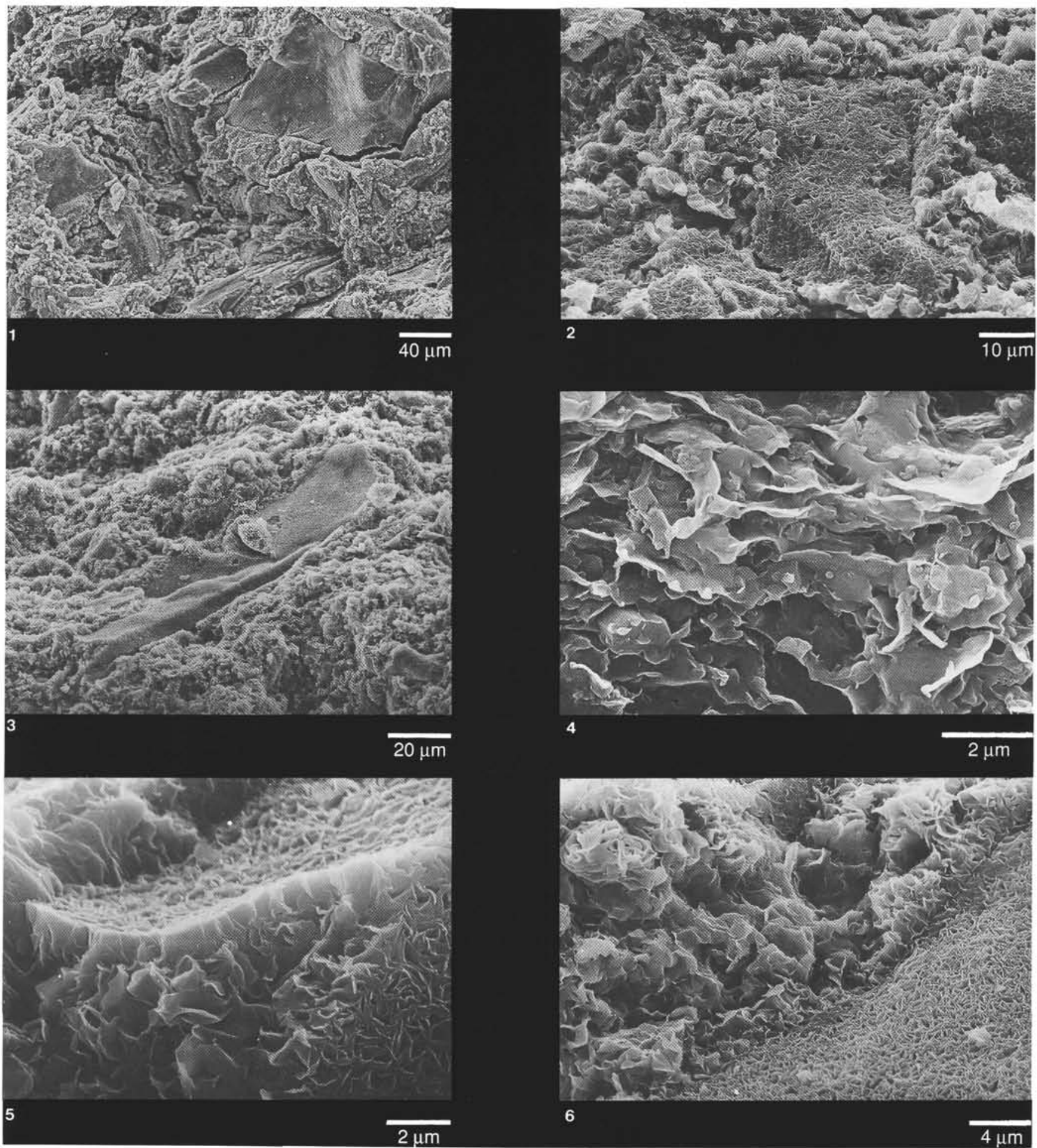

Plate 3. SEM pictures. 1-3, 5, 6. Sample 123-765C-60R-5, 120-123 cm; 1, altered and smectite-replaced glass shards; 2, 3, overgrown and smectite-replaced intraclasts; 5, 6, "honeycomb texture," detail; 4. Sample 123-765C-60R-1, 112-115 cm: elite fabric in background claystone. 


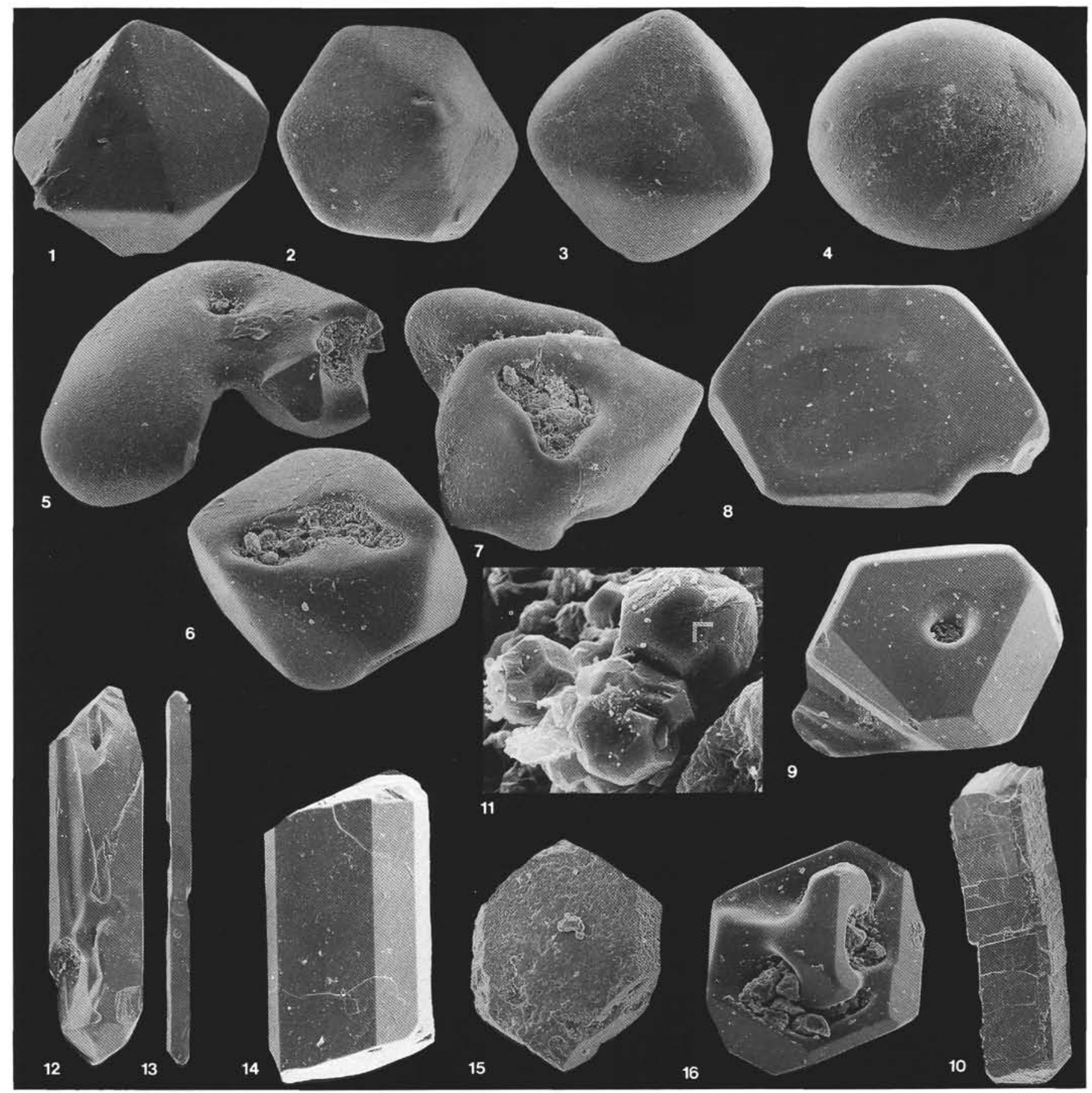

Plate 4. SEM pictures of authigenic minerals in bentonites. 1-3. Sample 123-765C-61R-1, 64-67 cm. SiOz-rich crystals to spherical crystals ([?] quartz). 4-8. Sample 123-765C-61R-1, 64-67 cm; "bubble-wall" glass shards. 9, 10. Idiomorphic ilmenite crystals; Sample 123-765C-57R-7, 8-12 cm. 11. Cu-oxide crystals; 123-765C-61R-1, 64-67 cm. 12, 13. Long prismatic zircon crystals; Sample 123-765C-61R-1, 64-67 cm. 14. Short prismatic apatite; Sample 123-765C-61R-1 64-67 cm. 15. Idiomorphic barite; Sample 123-765C-59R-3, 63-66 cm. 16. Idiomorphic K-feldspar; Sample 123-765C-59R-3, 63-66 cm. 